\title{
Prospecting Potential of the Yanjingou Gold Deposit in the East Kunlun Orogen, NW China: Evidence from Primary Halo Geochemistry and In Situ Pyrite Thermoelectricity
}

\author{
Jinjian Wu ${ }^{1,2,3}$, Qingdong Zeng $1,2,3, *$, Zhanhao Wei ${ }^{4}$, Hongrui Fan $\left.{ }^{1,2,3}{ }^{(}\right)$, Kuifeng Yang ${ }^{1,2,3}$, Zheming Zhang ${ }^{1,2,3}$, \\ Xinghui Li ${ }^{1,3}$, Gaizhong Liang ${ }^{1,2,3}$ and Fan Xia ${ }^{5}$ \\ 1 Key Laboratory of Mineral Resources, Institute of Geology and Geophysics, Chinese Academy of Sciences, \\ Beijing 100029, China; wujinjian19@mails.ucas.ac.cn (J.W.); fanhr@mail.iggcas.ac.cn (H.F.); \\ yangkuifeng@mail.iggcas.ac.cn (K.Y.); zhangzheming17@mails.ucas.ac.cn (Z.Z.); 1xh@mail.iggcas.ac.cn (X.L.); \\ lianggaizhong@mail.iggcas.ac.cn (G.L.) \\ 2 Innovation Academy for Earth Science, Chinese Academy of Sciences, Beijing 100029, China \\ 3 College of Earth and Planetary Sciences, University of Chinese Academy of Sciences, Beijing 100049, China \\ 4 First Institute Geology and Mineral Exploration of Qinghai Province, Qinghai 810600, China; \\ qhszhw@163.com \\ 5 State Key Laboratory of Environmental Geochemistry, Institute of Geochemistry, Chinese Academy of \\ Sciences, Guizhou 550081, China; xiafan@mail.gyig.ac.cn \\ * Correspondence: zengqingdong@mail.iggcas.ac.cn
}

Citation: Wu, J.; Zeng, Q.; Wei, Z.; Fan, H.; Yang, K.; Zhang, Z.; Li, X.; Liang, G.; Xia, F. Prospecting Potential of the Yanjingou Gold Deposit in the East Kunlun Orogen, NW China: Evidence from Primary Halo Geochemistry and In Situ Pyrite Thermoelectricity. Minerals 2021, 11, 1117. https://doi.org/10.3390/ $\min 11101117$

Academic Editor: António Manuel Nunes Mateus

Received: 10 September 2021

Accepted: 8 October 2021

Published: 12 October 2021

Publisher's Note: MDPI stays neutral with regard to jurisdictional claims in published maps and institutional affiliations.

Copyright: (c) 2021 by the authors. Licensee MDPI, Basel, Switzerland. This article is an open access article distributed under the terms and conditions of the Creative Commons Attribution (CC BY) license (https:// creativecommons.org/licenses/by/ $4.0 /)$.

\begin{abstract}
The Wulonggou Au district in the East Kunlun Orogen is one of the most important Au producing regions in China. The Yanjingou Au deposit occurs within a shear zone in the northeastern Wulonggou Au district. Based on detailed field investigations, geochemical data for the primary halo, and in situ thermoelectric data for pyrite, the following key results were obtained: (1) the Yanjingou Au deposit has the fractured-altered-rock type gold mineralization that is arsenopyriterich; (2) elemental correlations and cluster analysis show that $\mathrm{Au}$ and As are the most diagnostic elements; (3) geochemical data for the primary halo indicate the deposit is a shallow supra-ore halo ore body; and (4) in situ pyrite thermoelectric data show that the proportion of P-type pyrite is $>80 \%$ and the detachment rate is $50 \%$, which can be inferred that the location of the ore body is shallow. Based on our data, we present a mineralization prediction model for the ore body. The Yanjingou Au deposit has a good mineralization and high prospecting potential, with at least half of the ore body being concealed at depth, which has important scientific guiding significance for the breakthrough of prospecting and exploration.
\end{abstract}

Keywords: Yanjingou Au deposit; primary halo geochemistry; in situ pyrite thermoelectric data; prospecting potential; East Kunlun Orogen

\section{Introduction}

Orogenic Au deposits account for one third of global Au resources and are the most important Au source [1]. Such deposits are spatially and temporally related to igneous and/or greenschist- to amphibolite-facies metamorphic rocks [2] and are thought to be formed from fluids that exsolve from coeval intrusive magmas or by metamorphic devolatilization of volcanic-sedimentary rocks [3-5]. Studies of orogenic Au deposits can help guide prospecting and exploration for such Au resources.

The East Kunlun Orogen (EKO) is an important poly-metallogenic belt. Two Au districts are located in this orogenic belt (Figure 1), which are the Gouli Au district ( $>110 \mathrm{t}$ $\mathrm{Au}$; [6]) and Wulonggou Au district (>70 t Au; [7]). The Au deposits in these districts are similar to orogenic Au deposits and consist of fracture-hosted pervasive alteration-type and quartz-sulfide vein-type mineralization $[6,8,9]$. The focus of this study is the Yanjingou $\mathrm{Au}$ deposit, located near the northern margin of the Wulonggou Au district. The Yanjingou 
Au deposit contains a medium-large amount of proven and inferred resources and records favorable mineralization conditions [10].

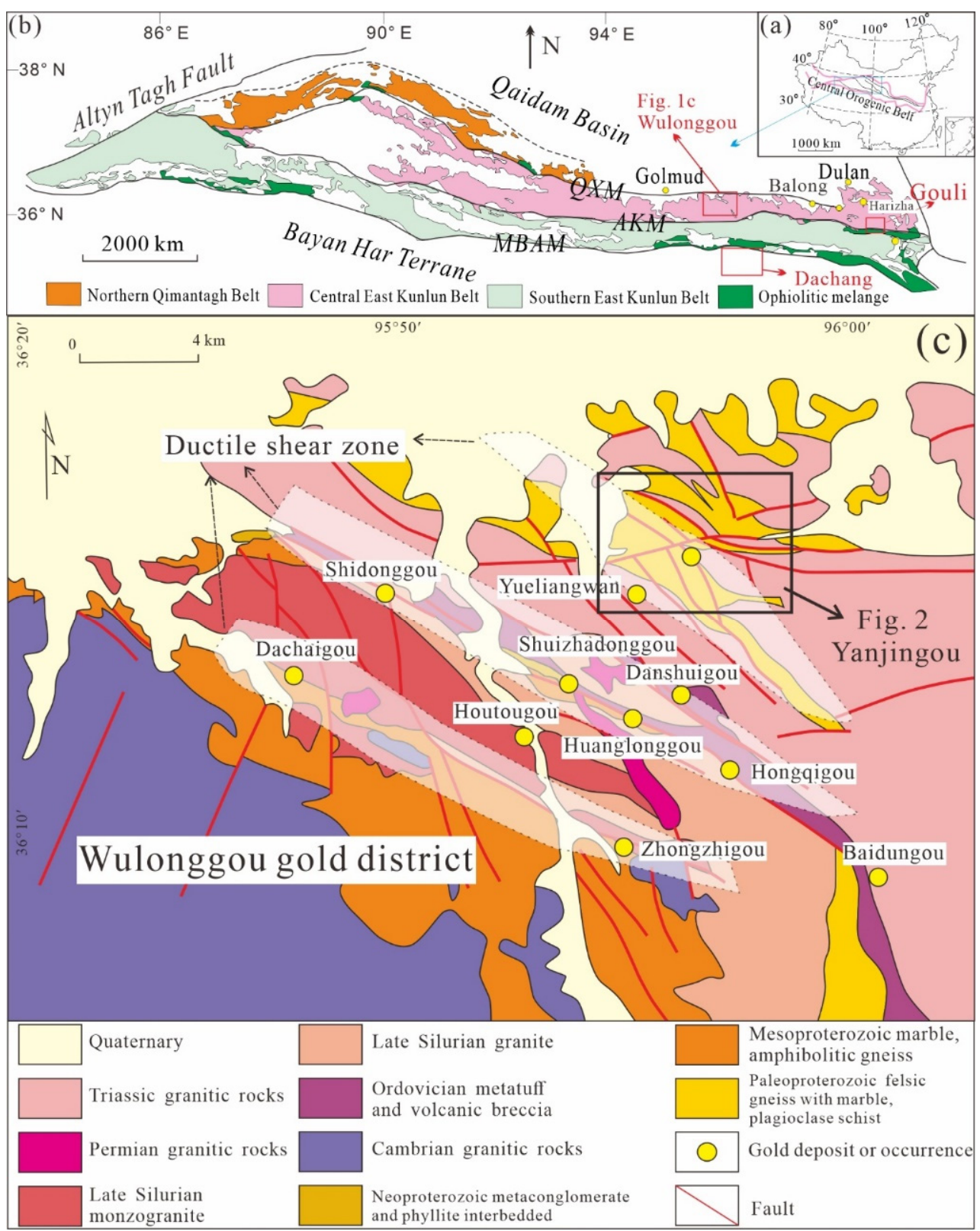

Figure 1. (a) Tectonic map of the study area, (b) Geological map of the East Kunlun Orogen, and (c) Geological map of the Wulonggou Au district (modified after [9]).

Previous studies have been conducted on the general geology of the Yanjingou Au deposit. The Yanjingou gold deposit is generally considered to have been formed in middle Triassic, which has a zircon fission-track (FT) age of ca. 235-216 Ma [11] and a Rb-Sr age of $237 \mathrm{Ma}$ for quartz-hosted fluid inclusions [12], and pyrite and arsenopyrite were the main Au-bearing minerals in the deposit [10]. Some studies have proposed that the mineralization history of the deposit is complex and was characterized by multi-stage hydrothermal activity and superimposed mineralization [13,14].

The Yanjingou Au deposit is the northernmost deposit in the Wulonggou Au district. After many years of mining, the Au reserves in this district have been declining, and there is an urgent need to explore for peripheral and deep deposits in this district. In this study, we conducted detailed field, mineralogical, and petrological investigations, along 
with in situ pyrite thermoelectric and primary halo geochemical analysis of the Yanjingou $\mathrm{Au}$ deposit. We use these data to constrain mineralization mechanisms and establish a prospecting prediction model for the deposit to guide subsequent exploration.

\section{Regional Geology}

The EKO is located in the western Central China Orogenic Belt in China (Figure 1a) and is bounded by the Bayan Har Terrane to the south, Qaidam Basin to the north, the Qinling Orogen to the east, and Altyn Tagh Fault to the west [9,15]. The EKO can be divided into three tectonic units from south to north (Figure 1b): Southern East Kunlun Belt (SEKB), Central East Kunlun Belt (CEKB), and Northern Qimantagh Belt (NQB). Three ophiolitic mélange zones separate these belts, which are the Muztagh-Buqingshan-Anemaqen ophiolitic mélange zone (MBAM) in the south, Aqikekulehu-Kunzhong ophiolitic mélange zone (AKM) in the center, and Qimantagh-Xiangride ophiolitic mélange zone (QXM) in the north. The QXM and NQB formed in the Qimantagh back-arc basin during the early Palaeozoic northward subduction of Proto-Tethyan oceanic lithosphere. The CEKB formed in a late Palaeozoic to Triassic active continental margin arc and early Palaeozoic island arc. The SEKB, MBAM, and AKM represent a long-lived and extensive accretionary subduction complex $[16,17]$. These tectonic units and ophiolitic mélange zones have been correlated to the evolution of the Proterozoic-early Palaeozoic Proto-Tethys Ocean (537-436 Ma) and late Palaeozoic-Mesozoic Palaeo-Tethys Ocean (345-243 Ma), based mainly on the ages of the ophiolites [16-18].

The Proterozoic basement is dominated by granitic gneisses and amphibolites, with minor migmatites and granitoids, which are overlain by Palaeozoic volcanic rocks and metamorphosed sedimentary rocks $[19,20]$. The igneous age of the Proterozoic granitic gneiss is $920 \mathrm{Ma}$, and it has a metamorphic age of 500-400 Ma [21]. The SEKB contains Mesozoic-Cainozoic volcanic rocks and sedimentary. Early Palaeozoic-Mesozoic granitoids (466-390 and 257-200 Ma) are widespread in the EKO [22-24]. These granitoids mainly include granodiorites, syenogranites, and monzogranites $[25,26]$ that were formed during the subduction of the Proto- and Palaeo-Tethyan oceanic plates [17,25]. Minor Cambrian-Ordovician mafic-ultramafic rocks (537-467 Ma) occur along the CEKB [27], and the SEKB that have the ages of Carboniferous and Cambrian-Ordovician are 345-332 Ma and 555-516 Ma, respectively [18,28].

The Wulonggou Au district is located in the central CEKB (Figure 1c). The older strata in this region consist mainly of three units [20,21]. The Palaeoproterozoic rocks are mainly felsic gneiss, with minor marble, plagioclase schist, quartz schist, and felsic schist. The Mesoproterozoic rocks are mainly marble, amphibolitic gneiss, and quartz schist. The Neoproterozoic rocks are mainly metaconglomerate and phyllite, which are interbedded with marble. The Ordovician rocks are mainly metatuff and volcanic breccia. There are also extensive granitic rocks of Cambrian, Silurian, Permian, and Triassic age $[23,29]$. The most prominent structural feature of the Wulonggou Au district is three large ductile shear zones (Figure 1c). All the Au deposits are distributed along shear zones. The three shear zones are NW-SE-trending and associated with small N-S-, NNE-SSW-, and E-W-trending secondary faults. There are more than 50 known deposits in the ore district, which are mainly $\mathrm{Au}$ deposits, along with some $\mathrm{Cu}, \mathrm{Pb}, \mathrm{Zn}, \mathrm{Sb}$, and Mo mineralization. The ages of magmatic activity and mineralization in the Middle Triassic are basically the same, so gold mineralization is closely related to the magmatism of the same period $[7,10-14,23,29]$. The Yanjingou Au deposit is one of the most important deposits in the northern part of the Wulonggou Au district [11].

\section{Ore Deposit Geology}

The Yanjingou Au deposit have the fractured-altered-rock type gold mineralization (Figure 2). The older strata in the deposit include Palaeoproterozoic felsic gneiss, plagioclase schist, and biotite-plagioclase gneiss, which are mainly distributed in the central to northeast part of the deposit $[10,11]$. The intrusive rocks in the Yanjingou deposit are 
mainly Triassic diorites and granites [10], including diorite and biotite diorite in the south, hornblende granodiorite with mafic microgranular enclaves in the center and north, and biotite granodiorite in the center of the deposit. Marble occurs locally in the central part of the mine.

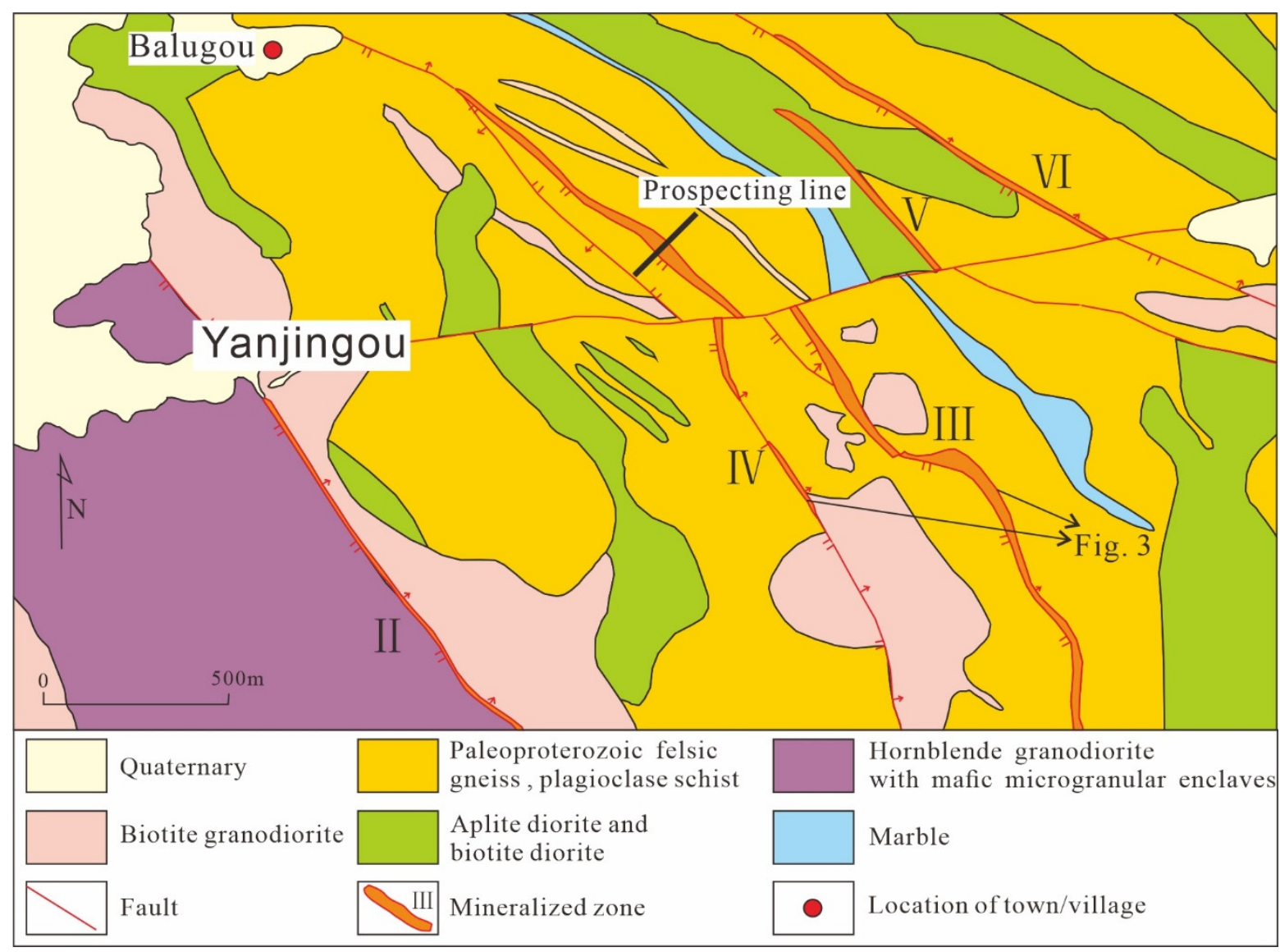

Figure 2. Geological map of the Yanjingou Au deposit (modified after [12]).

The Yanjingou Au deposit is controlled by the northernmost ductile shear zone of the Wulonggou Au district and cut by many secondary faults. The faults are mostly NW-SEtrending and dip towards the northeast. A small number of nearly E-W- and N-S-trending faults are also developed. These faults controlled the formation and distribution of the Yanjingou Au deposit.

The Yanjingou Au deposit contains six mineralized zones (I, II, III, IV, V, and VI). The $\mathrm{Au}$ ore bodies are veins, lenses, and long irregular bands distributed in NW-SEtrending fractured alteration zones, which are often branching, anastomosing, discontinuous, and variable in thickness. Among them, zones III and IV (Figure 2; Figure 3) are the main mineralized alteration zones, which have the large thickness (length $>3 \mathrm{~km}$ and width $=0.5-1.0 \mathrm{~km}$ ) and are high-grade and strongly altered. The ore body is NW-SE trending and dips $35-75^{\circ} \mathrm{NE}$. The occurrence of the ore bodies is almost the same as the faults. The ore bodies occur in the faults. Most of the faults are ore-conducting structures and ore-hosting structures, and some ore bodies are cut through by later faults. The mineralization was obviously controlled by the fracture zone. 


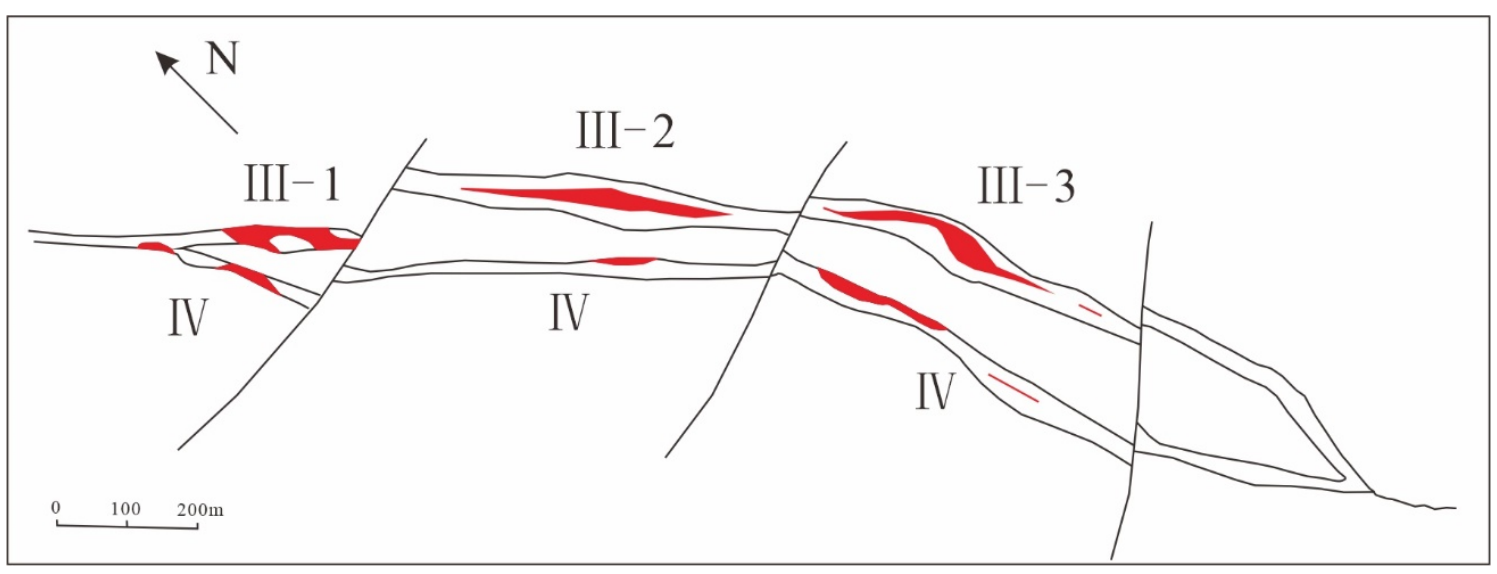

Figure 3. Horizontal projection of the III and IV mineralized belts in the Yanjingou ore body (modified after [10]).

Hand specimens of the ore generally have a massive texture and contain disseminated sulfides, although there are also abundant quartz sulfide veins. The sulfides exhibit solid solution exsolution and replacement textures. Pyrite and arsenopyrite are the main ore minerals in the Yanjingou Au deposit and show a close spatial relationship. The pyrite and arsenopyrite are often fractured and have a shape-preferred oriented (Figure 4e). Pyrite is an important Au-bearing mineral. A large amount of arsenopyrite surrounds pyrite and some Ag-bearing minerals, such as polybasite, reflecting a low mineralization temperature (Figure $4 \mathrm{f}, \mathrm{k}$ ). Some arsenopyrite has intergrown with pyrite, indicating their coeval formation (Figure 4g,l). Galena and sphalerite are rare in the Yanjinggou gold deposit, but they are found in other gold deposits in the Wulonggou gold district, such as Hongqigou gold deposit and Huanglonggou gold deposit. Therefore, Yanjinggou gold deposit is different from other deposits in the region to some extent. The accessory minerals include monazite and rutile.

The wall rocks of the deposit are highly altered, and the main alteration types are: silicification, chloritization, sericitization, carbonatization, and with pyrite mineralization and arsenopyrite mineralization. The silicification, sericitization with pyrite mineralization, and arsenopyrite mineralization were closely related to Au mineralization, and the ore grade is relatively high in the areas with strong silicification and arsenopyrite mineralization. 

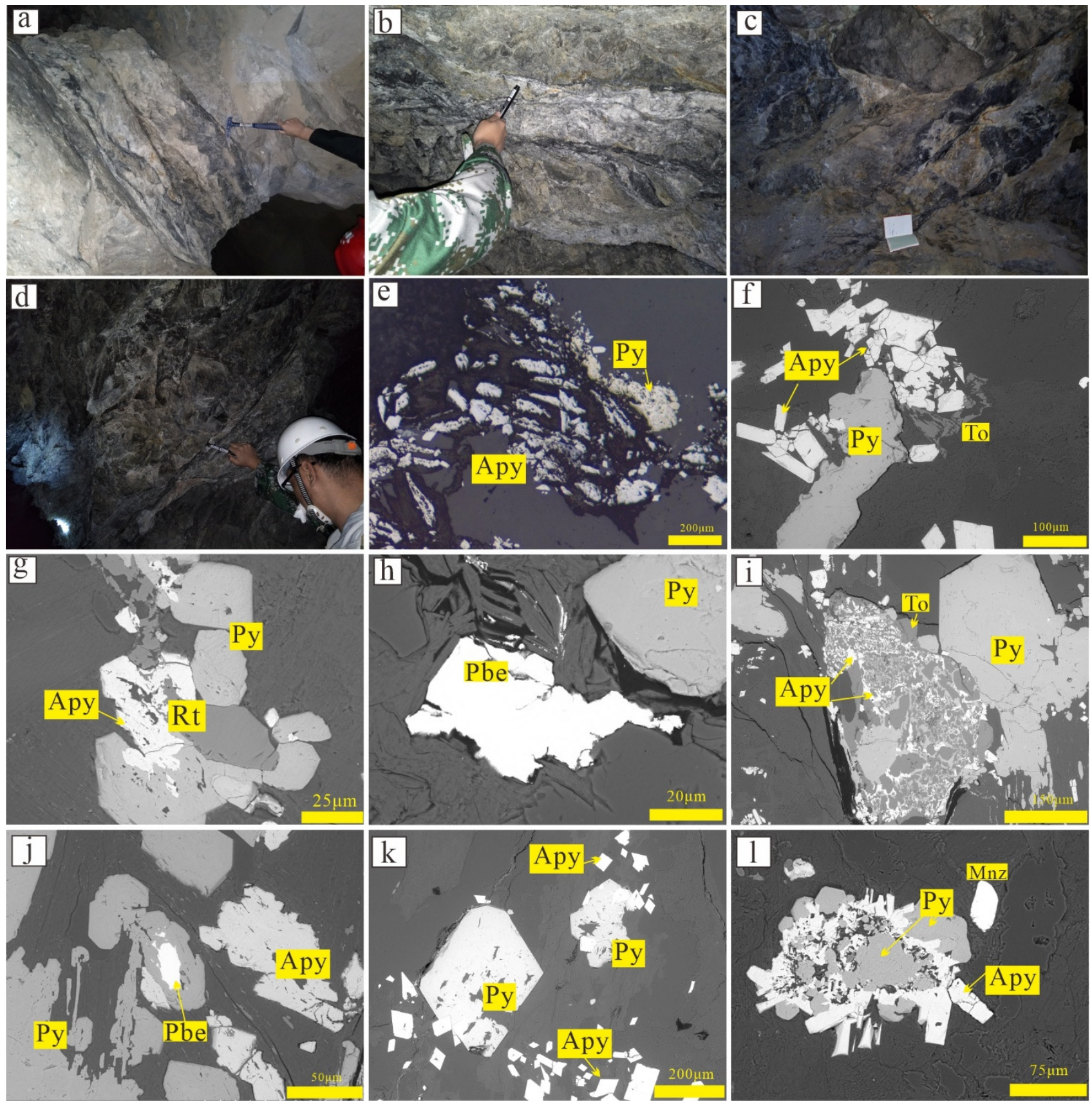

Figure 4. Images of the ore minerals and relationships between pyrite and arsenopyrite in the Yanjingou Au deposit. (a-d) field photos: the ore body is controlled by fault structure and is crushed; (e) Reflected light images; (f-l) Back-scattered electron images. Py = pyrite; Apy = arsenopyrite; $\mathrm{Pbe}=$ polybasite.

\section{Sample Descriptions and Analytical Methods}

We carried out detailed field geological surveys and laboratory analyses of the Yanjingou $\mathrm{Au}$ deposit. The sampling locations are shown in Figure 5 and representative samples were collected from different elevations. We used optical and scanning electron microscopy to examine the samples. The scanning electron microscope (TM4000plus) is equipped with Bruker Quantax 75 energy dispersive spectrometers and was used to identify minerals at the Institute of Geology and Geophysics, Chinese Academy of Sciences (IGGCAS), Beijing, China. Back-scattered electron images were acquired with an accelerating voltage of $20 \mathrm{kV}$. After detailed observations of the samples, elemental and in situ pyrite thermoelectric analyses were carried out. 


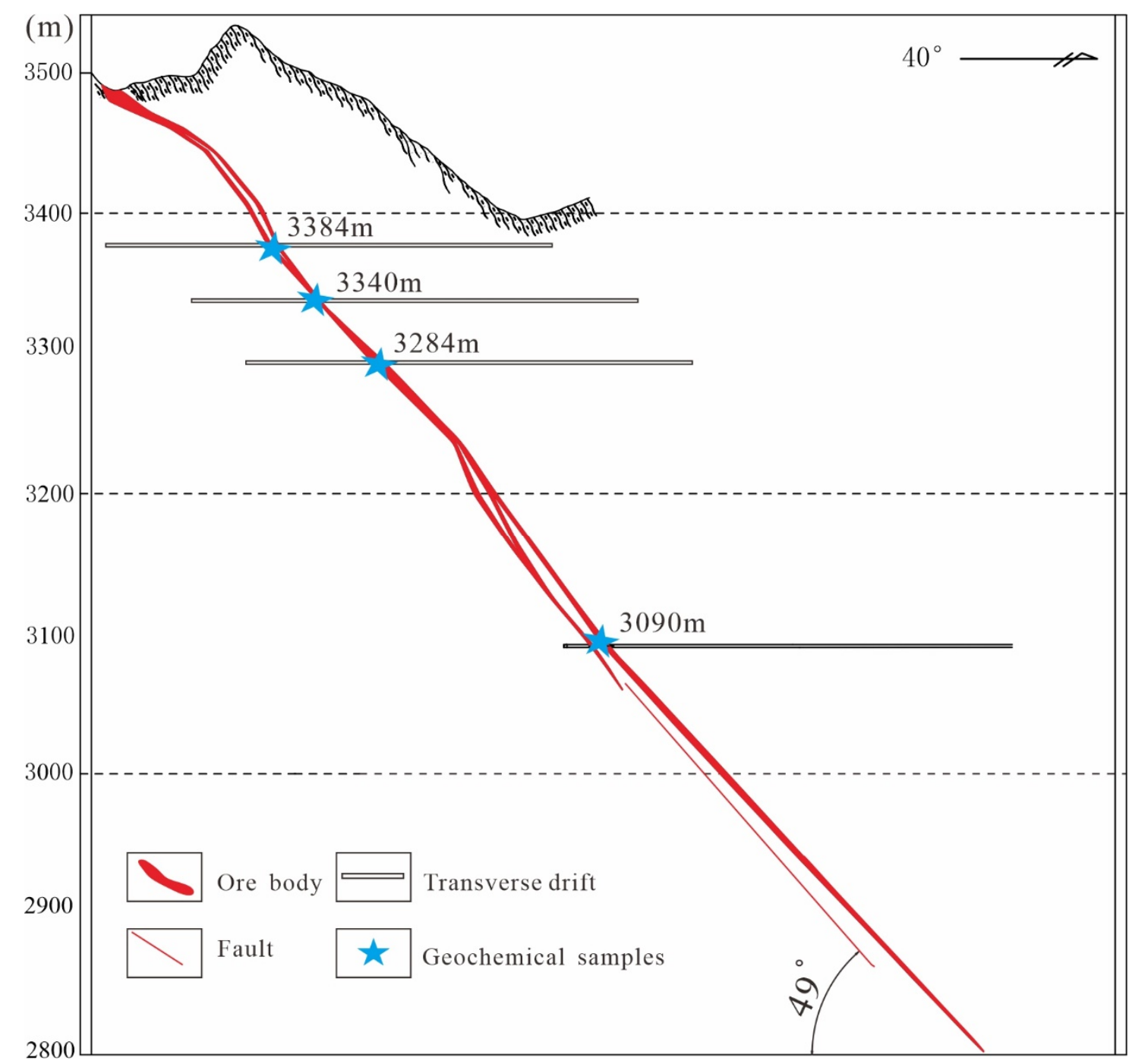

Figure 5. Schematic diagram of the sampling locations in the Yanjingou Au deposit.

\subsection{Petrography}

Samples of the ore body at $3384 \mathrm{~m}$ are shown in Figure $6 \mathrm{a}-\mathrm{c}$. This part of the ore body is shallow, and the extent of ore body fracturing is high. The ore body comprises soft carbonaceous material and contains quartz-pyrite veins. The main ore minerals are pyrite and arsenopyrite. The surrounding rock is dominated by amphibole gneiss with a pronounced lineation. Pyrite at this elevation is low in abundance and is deformed with an elongate morphology. The pyrite has a hypautomorphic to xenomorphic texture, with single mineral grains being 20-200 $\mu \mathrm{m}$ in size. Arsenopyrite is more abundant than pyrite, and the former is more broken than the pyrite, with grain sizes of 10-210 $\mu \mathrm{m}$.

The ore body at $3340 \mathrm{~m}$ elevation is characterized by silicification, chloritization, and quartz veins. The surrounding rocks are gneiss and diorite (Figure $6 \mathrm{~d}-\mathrm{f}$ ). The main ore minerals are arsenopyrite $(10-200 \mu \mathrm{m})$ and pyrite $(100-500 \mu \mathrm{m})$, which are slightly larger at this elevation than at $3384 \mathrm{~m}$. The deformation is weaker than at $3384 \mathrm{~m}$ elevation. The ore body contains carbonaceous material.

Samples of the ore body at $3284 \mathrm{~m}$ are shown in Figure $6 \mathrm{~g}-\mathrm{i}$. The ore body rocks vary from soft to hard and are relatively fractured. Sulfides are evenly distributed in carbonaceous and quartz veinlets, and pyrite veinlets are common. The arsenopyrite content at this elevation is lower than that at higher elevations. The sulfides have hypautomorphic 
to automorphic textures and are $10-150 \mu \mathrm{m}$ in size. The pyrite veinlets are sub-parallel to each other and contain pyrite of variable grain size.

The ore body at $3090 \mathrm{~m}$ elevation is deformed and fractured (Figure 6j-1), exhibits silicification, and contains grey quartz veins. The main ore minerals are pyrite and arsenopyrite. Accessory minerals include some rutile. The pyrite grains are large $(100-500 \mu \mathrm{m})$ and hypautomorphic to automorphic in texture. The arsenopyrite content is abundant, and it is hypautomorphic to automorphic in texture, with a grain size of 20-200 $\mu \mathrm{m}$.
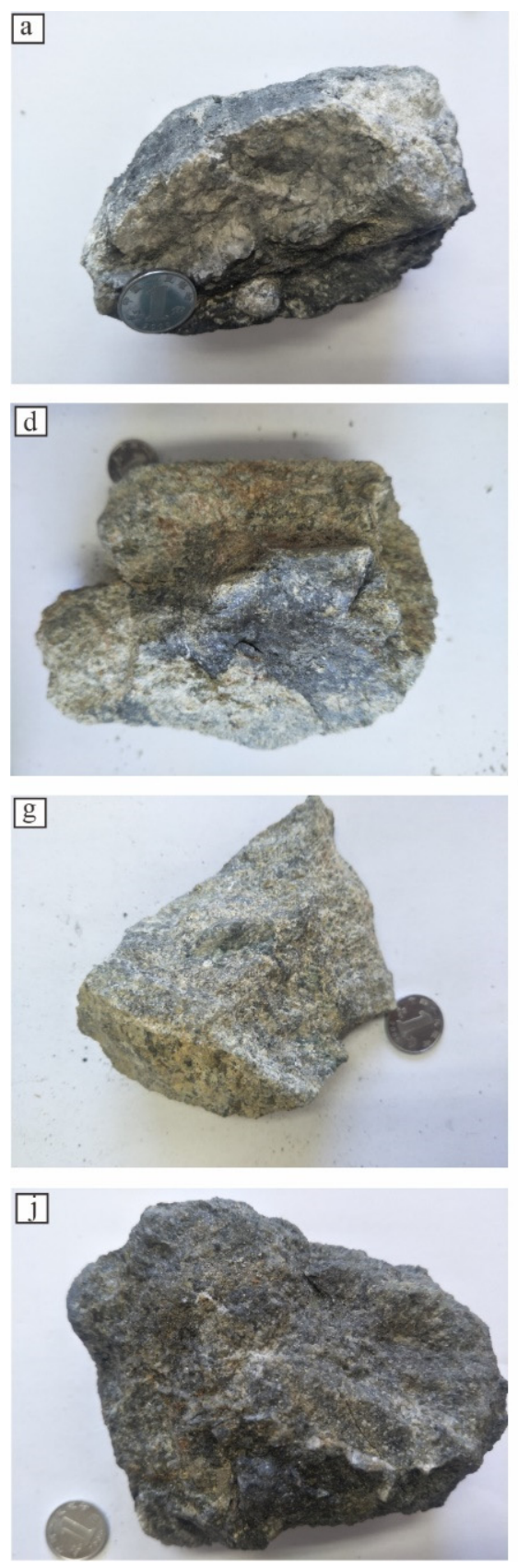
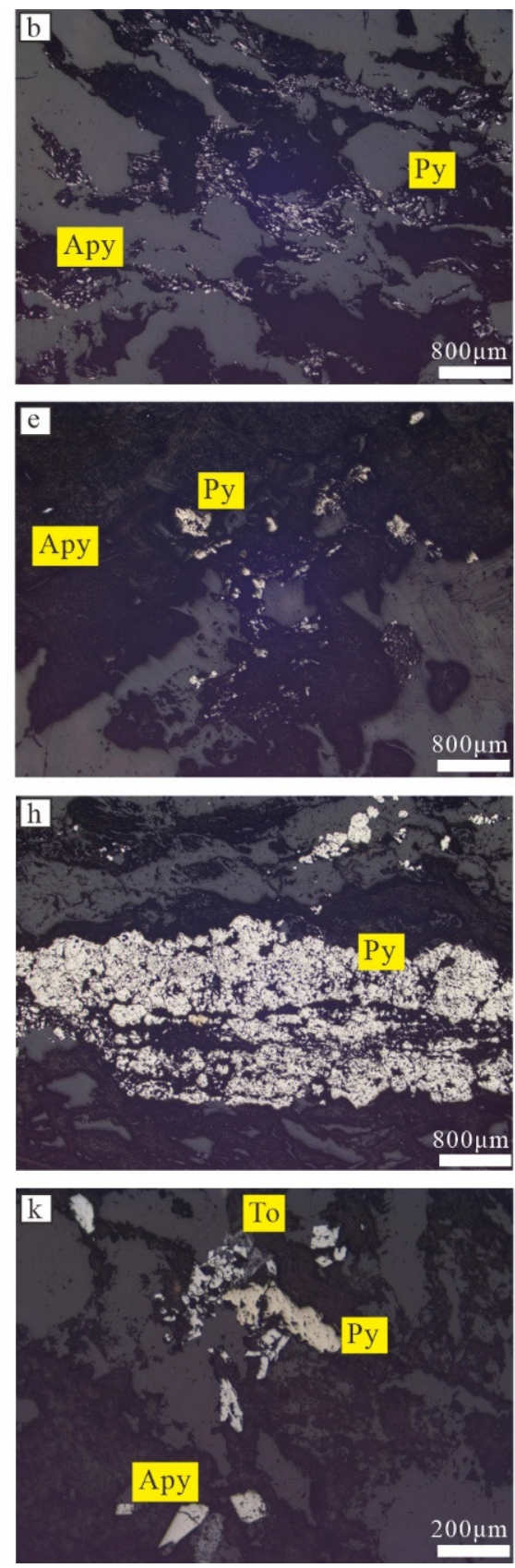
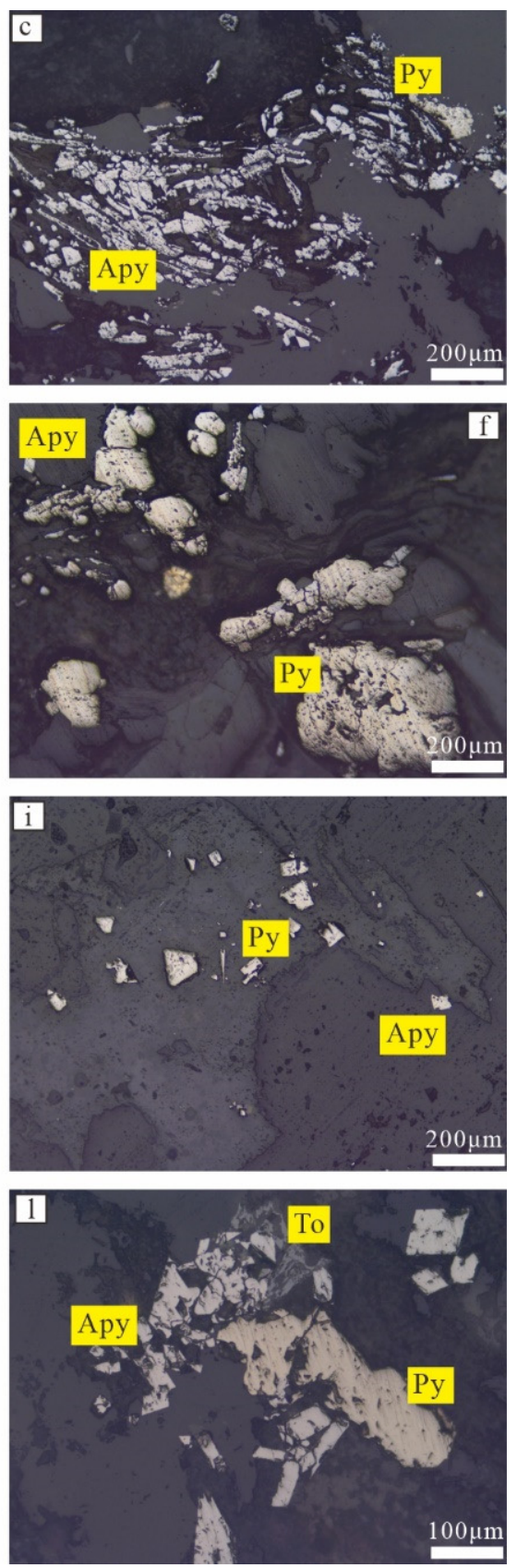

Figure 6. Hand specimens and photomicrographs of ores from various elevations in the Yanjingou Au deposit. (a-c): ore samples of $3384 \mathrm{~m} ;(\mathbf{d}-\mathbf{f})$ : ore samples of $3340 \mathrm{~m} ;(\mathbf{g}-\mathbf{i})$ : ore samples of $3284 \mathrm{~m} ;(\mathbf{j}-\mathbf{l})$ : ore samples of $3090 \mathrm{~m}$. Py = pyrite; Apy $=$ arsenopyrite; $\mathrm{To}=$ titanium oxide. 


\subsection{Primary Halo Geochemistry}

The samples for primary halo geochemistry were collected from the ore bodies at different elevations. Two to three ore body samples are collected at different elevations, and the average value is calculated after analysis to obtain the primary halo characteristics of the elevations. Ore samples from various elevations were geochemically analyzed at ALS Chemex, Guangzhou, China. The Au content was determined by fire assay inductively coupled plasma emission spectrometry (AU-ICP21) and fire assay gravimetry (AU-GRA21), with detection ranges of $0.001-10$ and $0.05-10,000 \mathrm{~g} / \mathrm{t}$, respectively. The $\mathrm{Hg}$ content was determined by inductively coupled plasma mass spectrometry (HG-MS42) with a detection range of $0.005-100 \mu \mathrm{g} / \mathrm{g}$. The contents of ultra-trace elements were determined by inductively coupled plasma mass spectrometry (ME-MS61) after tetracic acid digestion.

Correlation and cluster analyses were carried out on the measured elemental data, using the software of IBM SPSS Statistics 22 [30-32]. Instead of clustering for each element, we perform a cluster analysis on the degree of anomaly of each element, which means that the measured element value is divided by the background value of the mining area before cluster analysis. Data processing was carried out following previously published methods [30-32]. The basic equation is as follows:

$$
\operatorname{clr}(\mathrm{x})=\left\{\ln \frac{\mathrm{x}_{1}}{\mathrm{~g}(\mathrm{x})}, \ln \frac{\mathrm{x}_{2}}{\mathrm{~g}(\mathrm{x})}, \ldots, \ln \frac{\mathrm{x}_{\mathrm{D}}}{\mathrm{g}(\mathrm{x})}\right\} \cdot \mathrm{g}(\mathrm{x})=\left[\mathrm{x}_{1} \cdot \mathrm{x}_{2} \ldots \mathrm{x}_{\mathrm{D}}\right]^{1 / \mathrm{D}}
$$

where clr is the centered-logratio transformation and $\mathrm{g}(\mathrm{x})$ is the geometric mean.

Element zoning was quantified based on Li et al. (2016), Li et al. (2019), Li et al. (2020b), Beus and Gregorian (1977), and Harraz and Hamdy (2015) [33-36] as follows:

(1) The survey line metal concentration $M_{1}$ was defined, and each element anomaly in the ore body was calculated as follows:

$$
\mathrm{M}_{\mathrm{l}}=\sum \Delta \mathrm{x}\left[\mathrm{C}_{\mathrm{x}}-\mathrm{C}_{0}\right]
$$

where $\Delta \mathrm{x}$ is the point spacing on the survey line, $\mathrm{C}_{0}$ is the mean background concentration, and $C_{x}$ is the element concentration at a point in the anomaly.

(2) $M_{1}$ was standardized for each element anomaly as follows:

$$
\mathrm{B}_{\mathrm{i}}=10^{\mathrm{a}} \mathrm{M}_{\mathrm{i}}
$$

where $a$ and $i$ are positive integers.

(3) The zoning index is defined as follows:

$$
D_{i}=\frac{B_{i}}{\sum_{i=1}^{m} B_{i}}
$$

(4) The spatial variation of each zoning index was defined to obtain the maximum zoning index value for the survey line as follows:

$$
G=\sum_{i=1}^{n} \frac{D_{\max }}{D_{i}}
$$

where $G$ is the variation index, $D$ is the zoning index and $D_{\max }$ is its upper limit, and $\mathrm{N}$ does not contain the level number referred to by $D_{\max }$.

(5) The position of the sequence was first preliminarily identified according to the variation index. For example, when $G$ is large, the limiting variation index of most elements in the sequence would be in the upper part of the level, which indicates the upward migration of elements. In contrast, when $G$ is small, the limiting variation index of most elements in the sequence is in the lower part of the level, which indicates downward migration of elements. 
(6) The ladder difference of the variation index was calculated used to compare and test the position of the zoning. This was conducted to ensure the reliability of the determination of the initial variation position. The specific test indexes are as follows: if the initial zoning position is $>0$, it is estimated to be above the level; in contrast, a sequence of elements is judged to be below the level.

\subsection{In Situ Pyrite Thermoelectric Analyses}

The thermoelectric properties of pyrite were obtained using the thinsection in situ method [37]. The relative error of thermoelectric coefficient obtained by thinsection in situ test is less than $5 \%$, and the data quality is obviously better than that of traditional single mineral particle test method. In addition, the wafer method can improve the accuracy, reduce the cost, and improve the efficiency of the target mineral testing [37]. Pyrite of each elevation sample was tested. The specific test quantity is shown in the Supplementary Table S1. The thermoelectric property of pyrite is the electrical potential difference between the two ends of the mineral when there is a temperature difference between the two ends of a single pyrite grain. The internal performance of the mineral is the thermoelectric coefficient $(\alpha)$ and the external performance is the thermoelectric electromotive force $(E)$. Various factors affect the thermoelectric properties of pyrite, including temperature, depth, and trace element content. Thermoelectricity includes three parameters: the thermoelectric coefficient, thermoconductivity type, and the thermoelectromotive force. Thermoconductivity type can be classified into hole type (P-type) and electronic type (N-type) [38]. The thermoelectric coefficient $\alpha=\Delta \mathrm{E} / \Delta \mathrm{t}$ (where $\alpha$ is the thermoelectric coefficient $\left(\mathrm{mV} /{ }^{\circ} \mathrm{C}\right)$, $\Delta \mathrm{E}$ is the thermoelectromotive force $(\mathrm{mV})$, and $\Delta \mathrm{t}$ is the temperature difference $\left({ }^{\circ} \mathrm{C}\right)[39,40]$.

The sampling was conducted from top to bottom elevations, and fresh and representative samples were selected and cut into $\mathrm{Cu}$ sheets (Figure 7) with a thickness of $0.1-0.7 \mathrm{~mm}$ for in situ thermoelectric analysis. Pyrite grains were exposed at both ends of the sheets. A parallel-moving pen was used for the in situ contact test and an image was used to observe the pyrite relationships. The thermoelectric data were collected by computer software. The analyses were undertaken with a BHTE-08 instrument at the Mineral Typing Laboratory of the China University of Geosciences, Beijing, China. The hot and cold end-temperatures were set to $125^{\circ} \mathrm{C}$ and $29^{\circ} \mathrm{C}$, respectively, and the activation temperature was $95^{\circ} \mathrm{C}$.

The thermoelectric coefficient of pyrite was first measured, and then the degree of denudation was calculated as follows. Firstly, the thermoelectric parameter (XNP) was calculated as follows:

$$
X_{N P}=\left(2 f_{I}+f_{I I}\right)-\left(f_{I V}+2 f_{V}\right),
$$

where $\mathrm{f}$ is the percentage of the thermoelectric coefficient of the corresponding pyrite sample, I is the thermoelectric coefficient at $>400 \mu \mathrm{V} /{ }^{\circ} \mathrm{C}$, II is the thermoelectric coefficient from 400 to $200 \mu \mathrm{V} /{ }^{\circ} \mathrm{C}$, IV is the thermoelectric coefficient from 0 to $-200 \mu \mathrm{V} /{ }^{\circ} \mathrm{C}$, and V is the thermoelectric coefficient at $<-200 \mu \mathrm{V} /{ }^{\circ} \mathrm{C}$. The denudation rate $(\gamma)$ of the ore body was calculated as follows [41-43]:

$$
\gamma=50-\mathrm{X}_{\mathrm{NP}} / 4
$$



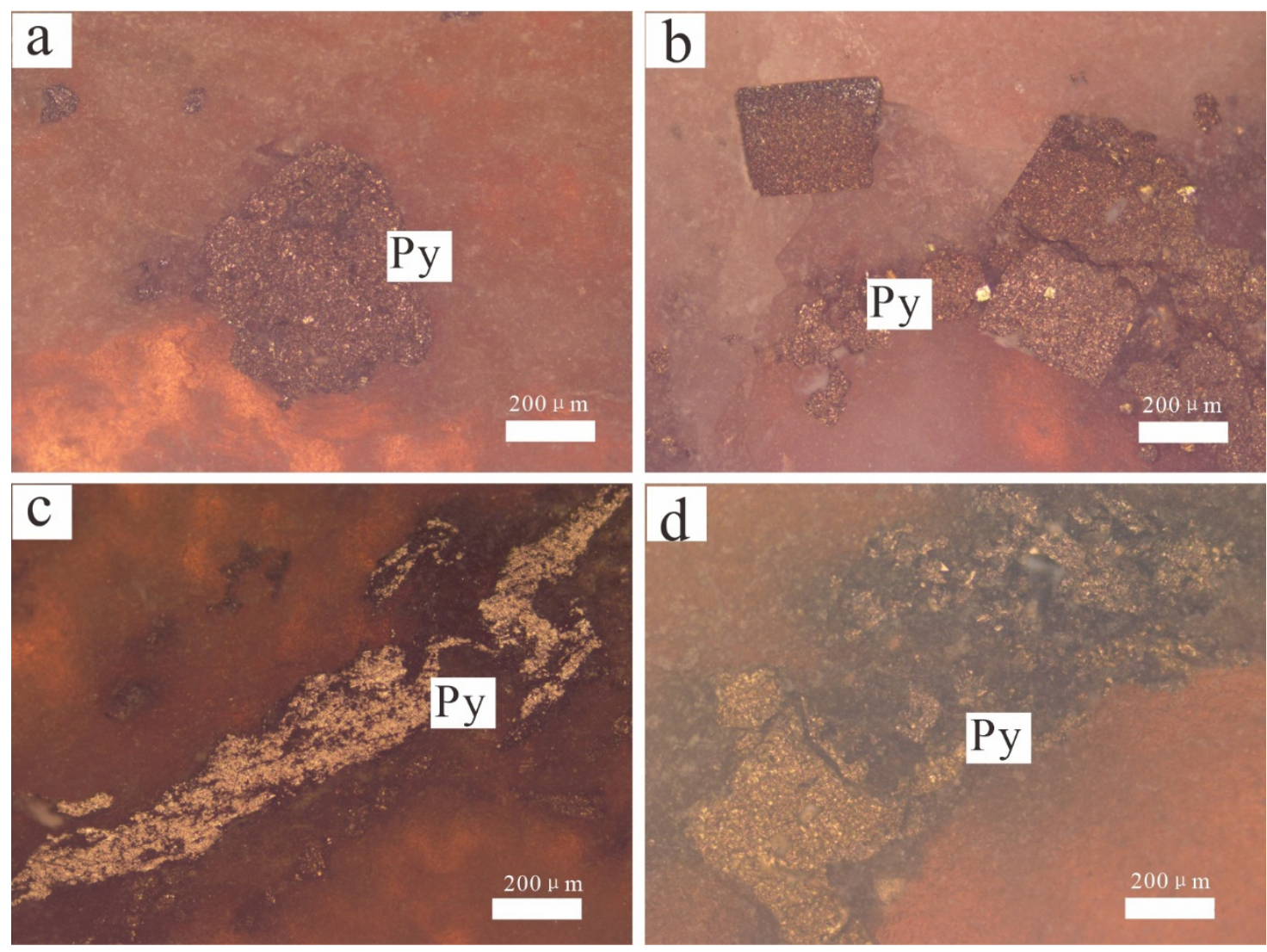

Figure 7. Copper coatings used for the pyrite thermoelectric tests. (a,b): euhedral pyrite; (c,d): subhedral to anhedral pyrite. Py $=$ pyrite.

\section{Results}

\subsection{Primary Halo Geochemistry}

5.1.1. Elemental Correlation Analysis

Based on the previous experience and the theory of primary halo research $[33,34,44]$, this paper analyses the input correlation of 21 kinds of elements related to gold deposits and uses the correlation coefficient to understand the affinity of each element, and then reflects the correlation of variable elements. The elements for correlation analysis are $\mathrm{Au}$, $\mathrm{Ag}, \mathrm{Cu}, \mathrm{Pb}, \mathrm{Zn}, \mathrm{Cd}, \mathrm{Sb}, \mathrm{W}, \mathrm{Sn}, \mathrm{As}, \mathrm{Hg}, \mathrm{Ba}, \mathrm{Sc}, \mathrm{Bi}, \mathrm{Mo}, \mathrm{Mn}, \mathrm{Co}, \mathrm{V}, \mathrm{Ni}, \mathrm{Ti}$, and Cr. The correlation coefficient matrix of trace elements obtained by analysis is listed in Table 1 . The elements that are positively correlated with $\mathrm{Au}$ are $\mathrm{As}>\mathrm{Cu}>\mathrm{Co}>\mathrm{Ti}>\mathrm{Cd}>\mathrm{Zn}>\mathrm{Ag}>\mathrm{Ba}$ $>\mathrm{Hg}>\mathrm{Ni}>\mathrm{Sb}>\mathrm{Mo}>\mathrm{Bi}>\mathrm{W}>\mathrm{Pb}$. The elements negatively correlated with Au are $\mathrm{Sc}<$ $\mathrm{Mn}<\mathrm{Cr}<\mathrm{Sn}$. 
Table 1. Correlation coefficient matrix for trace elements.

\begin{tabular}{|c|c|c|c|c|c|c|c|c|c|c|c|c|c|c|c|c|c|c|c|c|c|}
\hline Element & $\mathbf{A u}$ & $\mathrm{Ag}$ & $\mathrm{Cu}$ & $\mathbf{P b}$ & $\mathrm{Zn}$ & $\mathrm{Cd}$ & $\mathrm{Sb}$ & W & Sn & As & $\mathrm{Hg}$ & Ba & Sc & $\mathbf{B i}$ & Mo & Mn & Co & $\mathbf{V}$ & $\mathrm{Ni}$ & $\mathrm{Ti}$ & $\mathrm{Cr}$ \\
\hline $\mathrm{Au}$ & 1 & 0.333 & 0.619 & 0.024 & 0.405 & 0.419 & 0.167 & 0.048 & -0.366 & 0.685 & 0.245 & 0.31 & -0.048 & 0.049 & 0.095 & -0.048 & 0.524 & 0.524 & 0.214 & 0.476 & -0.143 \\
\hline $\mathrm{Ag}$ & & 1 & 0.833 & 0.690 & 0.667 & 0.719 & 0.738 & -0.167 & -0.122 & 0.507 & 0.600 & 0.405 & -0.310 & 0.683 & 0.643 & -0.333 & 0.381 & 0.571 & 0.810 & 0.048 & 0.595 \\
\hline $\mathrm{Cu}$ & & & 1 & 0.429 & 0.857 & 0.874 & 0.381 & -0.119 & -0.268 & 0.482 & 0.709 & 0.452 & -0.095 & 0.488 & 0.429 & -0.095 & 0.500 & 0.667 & 0.667 & 0.167 & 0.333 \\
\hline $\mathrm{Pb}$ & & & & 1 & 0.476 & 0.539 & 0.595 & -0.048 & 0.317 & 0.507 & 0.300 & 0.048 & -0.071 & 0.854 & 0.310 & -0.762 & 0.143 & 0.262 & 0.548 & 0.167 & 0.119 \\
\hline $\mathrm{Cd}$ & & & & & & 1 & 0.335 & 0.048 & -0.037 & 0.542 & 0.851 & 0.443 & 0.275 & 0.724 & 0.539 & -0.036 & 0.647 & 0.731 & 0.635 & 0.335 & 0.252 \\
\hline $\mathrm{Sb}$ & & & & & & & 1 & -0.333 & -0.244 & 0.52 & 0.136 & 0.381 & -0.286 & 0.512 & 0.619 & -0.262 & 0.310 & 0.405 & 0.381 & 0.024 & 0.429 \\
\hline W & & & & & & & & 1 & 0.805 & 0.368 & 0.327 & 0.333 & 0.619 & 0.146 & 0.048 & -0.119 & 0.524 & 0.429 & 0.357 & 0.786 & -0.095 \\
\hline Sn & & & & & & & & & 1 & 0.156 & 0.140 & 0.073 & 0.488 & 0.325 & -0.098 & -0.488 & 0.146 & 0.122 & 0.317 & 0.512 & -0.146 \\
\hline As & & & & & & & & & & 1 & 0.407 & 0.457 & 0.241 & 0.585 & 0.444 & -0.355 & 0.774 & 0.736 & 0.495 & 0.786 & -0.013 \\
\hline $\mathrm{Ba}$ & & & & & & & & & & & & 1 & 0.452 & 0.098 & 0.310 & 0.143 & 0.786 & 0.881 & 0.357 & 0.548 & 0.119 \\
\hline Sc & & & & & & & & & & & & & 1 & 0.122 & -0.048 & 0.214 & 0.595 & 0.476 & -0.595 & -0.385 & -0.675 \\
\hline $\mathrm{Bi}$ & & & & & & & & & & & & & & 1 & 0.659 & -0.415 & 0.415 & 0.439 & 0.708 & 0.293 & 0.366 \\
\hline Mo & & & & & & & & & & & & & & & 1 & 0.214 & 0.548 & 0.524 & 0.667 & 0.119 & 0.810 \\
\hline $\mathrm{Mn}$ & & & & & & & & & & & & & & & & 1 & 0.167 & 0.048 & -0.310 & -0.19 & 0.214 \\
\hline Co & & & & & & & & & & & & & & & & & 1 & 0.952 & 0.476 & 0.810 & 0.119 \\
\hline V & & & & & & & & & & & & & & & & & & 1 & 0.595 & 0.714 & 0.190 \\
\hline $\mathrm{Ni}$ & & & & & & & & & & & & & & & & & & & 1 & 0.286 & 0.667 \\
\hline $\mathrm{Ti}$ & & & & & & & & & & & & & & & & & & & & 1 & -0.310 \\
\hline $\mathrm{Cr}$ & & & & & & & & & & & & & & & & & & & & & 1 \\
\hline
\end{tabular}




\subsubsection{Cluster Analysis of the Element Anomalies}

In order to further understand the element combination characteristics of the Yanjingou gold deposit, we conducted cluster analysis on the data, which can effectively reflect the characteristics of elements, including which elements are common and which occur at anomalously high concentration. The principle is to divide the multivariate data set into some meaningful multivariate isomorphic groups [30]. Because we do not perform cluster analysis on each element, but analyze its abnormality, our results show the classification characteristics of different element abnormalities. As shown in Figure 8, each element is obviously divided into three groups: the first type of anomalous clustering is $\mathrm{Au}$, the second type comprises $\mathrm{As}$, and the third type comprises other elements $(\mathrm{Ba}, \mathrm{Ti}, \mathrm{Cu}, \mathrm{Mo}$, $\mathrm{Hg}, \mathrm{Zn}, \mathrm{Co}, \mathrm{Bi}, \mathrm{Sb}, \mathrm{W}, \mathrm{Ni}, \mathrm{Pb}, \mathrm{Cd}, \mathrm{Ag}$ ). It can be seen that $\mathrm{Au}$ and As are two kinds of obvious anomalies, which are the key elements of the Yanjingou gold deposit. They have great particularity in the mineralization process and element migration and distribution.

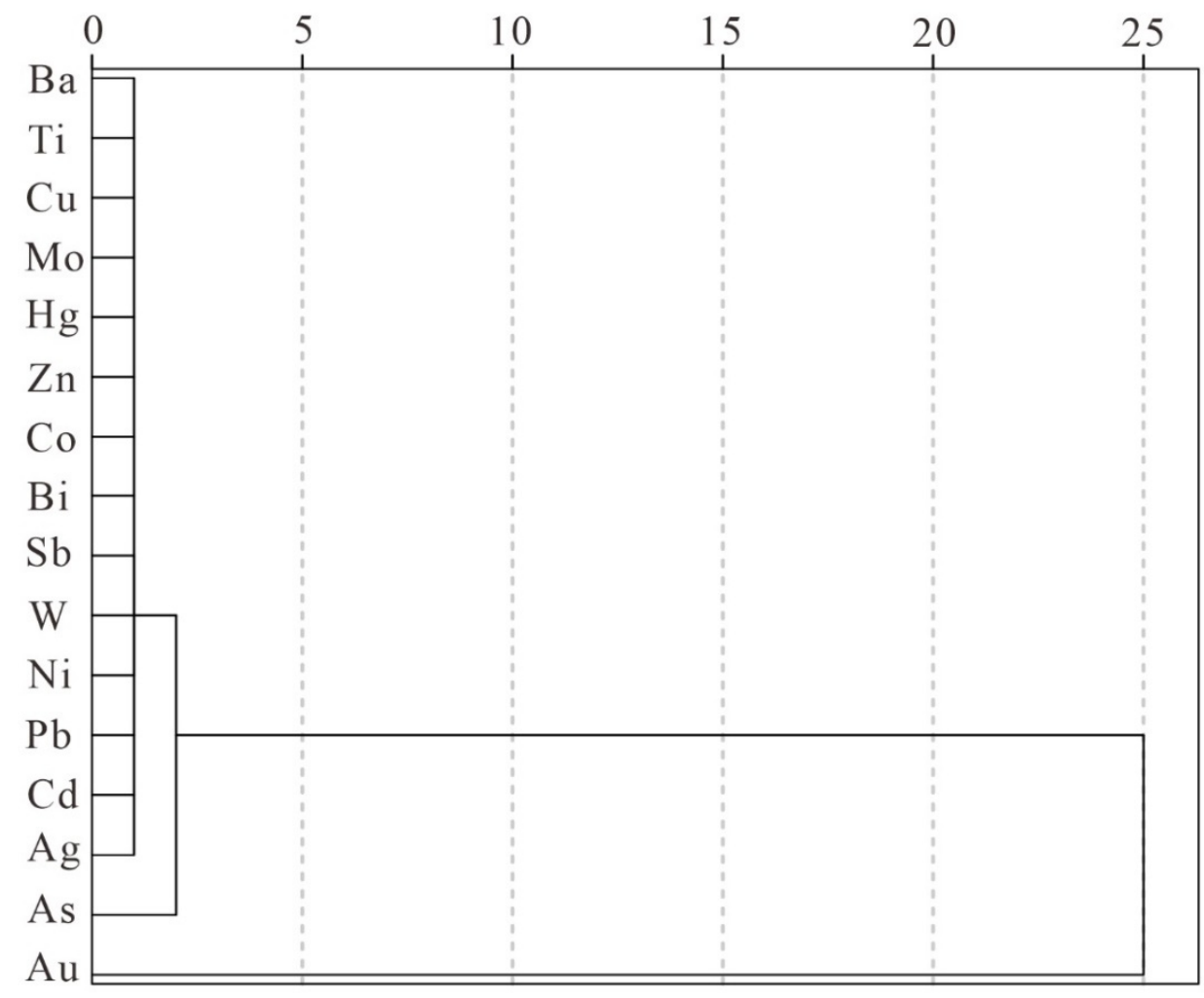

Figure 8. Cluster analysis diagram of element abnormality in the Yanjingou Au deposit.

\subsubsection{Element Zoning}

The zoning index and concentration center methods [35,45] were used to determine the zoning sequence of some elements that are closely related to Au. The zoning from 3384 to $3090 \mathrm{~m}$ elevations in the ore body is now described.

The zoning index method uses the data in Table 2 to calculate the amount of line metal of each section element and normalize it to the same order of magnitude to obtain the zoning index. The elemental concentrations of each elevation and background are listed in Table 3. The elevation of the maximum value of the zoning index for each element is the position of the element in the zoning sequence summary. When the maximum value of the zoning index of more than two elements is at the middle position of an elevation, the variability index is used to determine their relative position in a straight step. The zoning sequence is $\mathrm{Mo}-\mathrm{Au}-\mathrm{Ni}-\mathrm{W}-\mathrm{Sb}-\mathrm{Ag}-\mathrm{As}-\mathrm{Hg}$ from high to low relative to the wall-rock, and $\mathrm{Mo}-\mathrm{Au}-\mathrm{Sb}-\mathrm{Ag}-\mathrm{Ni}-\mathrm{As}-\mathrm{Hg}-\mathrm{W}$ relative to the Wulonggou Au district. 
Table 2. Axial zoning results for the Yanjingou ore body.

\begin{tabular}{|c|c|c|c|c|c|c|c|c|c|}
\hline \multicolumn{2}{|c|}{ Element } & As & $\mathrm{Hg}$ & $\mathrm{Sb}$ & Ag & $\mathrm{Au}$ & $\mathbf{W}$ & Mo & $\mathrm{Ni}$ \\
\hline \multirow{4}{*}{$\begin{array}{c}\text { Zoning index } \\
\text { method/ } \\
\text { wall-rock }\end{array}$} & $3384 \mathrm{~m}$ & 0.3318 & 0.0552 & 0.0351 & 0.0901 & 0.0737 & 0.1138 & 0.1888 & 0.1115 \\
\hline & $3340 \mathrm{~m}$ & 0.3553 & 0.0009 & 0.0141 & 0.0770 & 0.0814 & 0.3051 & 0.0249 & 0.1413 \\
\hline & $3284 \mathrm{~m}$ & 0.3047 & 0.0499 & 0.0783 & 0.1925 & 0.0134 & 0.0999 & 0.1355 & 0.1257 \\
\hline & $3090 \mathrm{~m}$ & 0.3984 & 0.0801 & 0.0014 & 0.0448 & 0.0430 & 0.2983 & 0.0578 & 0.0763 \\
\hline \multirow{2}{*}{\multicolumn{2}{|c|}{$\begin{array}{c}\text { Variation index } \\
\text { (gradient difference) }\end{array}$}} & $\mathrm{Au}$ & W & $\mathrm{Ni}$ & $\mathrm{Sb}$ & $\mathrm{Ag}$ & As & $\mathrm{Hg}$ & \\
\hline & & -6.8691 & -1.3960 & -1.7096 & -48.7073 & 0.3446 & 3.6291 & 88.3508 & \\
\hline \multirow{4}{*}{$\begin{array}{c}\text { Zoning index } \\
\text { method/ } \\
\text { Wulonggou } \\
\text { Au district }\end{array}$} & $3384 \mathrm{~m}$ & 0.3494 & 0.0694 & 0.0579 & 0.0932 & 0.0774 & 0.0547 & 0.2434 & 0.0547 \\
\hline & $3340 \mathrm{~m}$ & 0.4013 & 0.0278 & 0.0667 & 0.0830 & 0.0913 & 0.1850 & 0.1377 & 0.0074 \\
\hline & $3284 \mathrm{~m}$ & 0.3177 & 0.0610 & 0.0981 & 0.1989 & 0.0139 & 0.0523 & 0.1770 & 0.0810 \\
\hline & $3090 \mathrm{~m}$ & 0.4186 & 0.0949 & 0.0217 & 0.0457 & 0.0451 & 0.2499 & 0.1044 & 0.0197 \\
\hline \multirow{2}{*}{\multicolumn{2}{|c|}{$\begin{array}{c}\text { Variation index } \\
\text { (gradient difference) }\end{array}$}} & $\mathrm{Sb}$ & $\mathrm{Ag}$ & $\mathrm{Ni}$ & As & $\mathrm{Hg}$ & $\mathrm{W}$ & & \\
\hline & & -1.349 & 0.1774 & 8.3743 & 8.4496 & 6.3448 & 10.7024 & & \\
\hline \multirow{4}{*}{$\begin{array}{l}\text { Concentration } \\
\text { center method/ } \\
\text { wall-rock }\end{array}$} & $3384 \mathrm{~m}$ & 0.2594 & 0.2753 & 0.2507 & 0.2199 & 0.4319 & 0.1672 & 0.4411 & 0.2728 \\
\hline & $3340 \mathrm{~m}$ & 0.1225 & 0.0021 & 0.0445 & 0.0829 & 0.2102 & 0.1976 & 0.0256 & 0.1523 \\
\hline & $3284 \mathrm{~m}$ & 0.2961 & 0.3097 & 0.6946 & 0.5840 & 0.0975 & 0.1824 & 0.3936 & 0.3821 \\
\hline & $3090 \mathrm{~m}$ & 0.3220 & 0.4129 & 0.0102 & 0.1132 & 0.2604 & 0.4529 & 0.1397 & 0.1928 \\
\hline \multirow{2}{*}{\multicolumn{2}{|c|}{$\begin{array}{c}\text { Variation index } \\
\text { (gradient difference) }\end{array}$}} & As & $\mathrm{Hg}$ & $W$ & $\mathrm{Au}$ & Mo & $\mathrm{Sb}$ & $\mathrm{Ag}$ & $\mathrm{Ni}$ \\
\hline & & 4.9572 & 202.8333 & 7.4847 & 8.1441 & 21.4915 & -49.5108 & 4.5435 & 1.9274 \\
\hline Concentration & $3384 \mathrm{~m}$ & 0.2594 & 0.2712 & 0.2505 & 0.2196 & 0.4317 & 0.1201 & 0.3861 & 0.3043 \\
\hline center method/ & $3340 \mathrm{~m}$ & 0.1230 & 0.0448 & 0.1192 & 0.0807 & 0.2103 & 0.1678 & 0.0902 & 0.0169 \\
\hline Wulonggou & $3284 \mathrm{~m}$ & 0.2959 & 0.2995 & 0.5330 & 0.5883 & 0.0977 & 0.1439 & 0.3522 & 0.5652 \\
\hline Au district & $3090 \mathrm{~m}$ & 0.3217 & 0.3844 & 0.0974 & 0.1114 & 0.2603 & 0.5682 & 0.1715 & 0.1135 \\
\hline \multirow{2}{*}{\multicolumn{2}{|c|}{$\begin{array}{c}\text { Variation index } \\
\text { (gradient difference) }\end{array}$}} & As & $\mathrm{Hg}$ & W & $\mathrm{Au}$ & Mo & $\mathrm{Sb}$ & $\mathrm{Ag}$ & $\mathrm{Ni}$ \\
\hline & & 4.9427 & 11.2766 & 12.0635 & 8.1316 & 7.6277 & 1.1266 & 4.6866 & 30.3070 \\
\hline
\end{tabular}

Table 3. Elemental concentrations of each elevation and background.

\begin{tabular}{|c|c|c|c|c|c|c|c|}
\hline (ppm) & $3384 \mathrm{~m}$ & $3340 \mathrm{~m}$ & $3284 \mathrm{~m}$ & $3090 \mathrm{~m}$ & Wulonggou & Wall-Rock & Whole Ore Body \\
\hline As & 8066.7 & 3835 & 9200 & 10000 & 18.4 & 49.5 & 7533.75 \\
\hline $\mathrm{Hg}$ & 0.023 & 0.01 & 0.025 & 0.03 & 0.00736 & 0.01 & 0.021 \\
\hline $\mathrm{Sb}$ & 134.2 & 64.3 & 284.5 & 52.7 & 0.89 & 49.235 & 144.1 \\
\hline $\mathrm{Ba}$ & 270 & 240 & 280 & 240 & 553 & 965 & 261.25 \\
\hline $\mathrm{Pb}$ & 6.5 & 6.4 & 360.8 & 9.7 & 33 & 17.8 & 95.45 \\
\hline $\mathrm{Ag}$ & 2.2 & 0.86 & 5.82 & 1.16 & 0.071 & 0.04 & 2.65 \\
\hline $\mathrm{Au}$ & 17.8 & 8.68 & 4.04 & 10.75 & 0.0039 & 0.016 & 11.21 \\
\hline $\mathrm{Zn}$ & 202.7 & 45.5 & 277 & 177 & 91 & 84 & 178.75 \\
\hline $\mathrm{Cu}$ & 23.3 & 6.8 & 27.3 & 7.7 & 33 & 8.45 & 18.24 \\
\hline $\mathrm{W}$ & 3.2 & 3.7 & 3.45 & 7.9 & 1.94 & 0.45 & 3.98 \\
\hline $\mathrm{Bi}$ & 0.053 & 0.03 & 0.21 & 0.15 & 0.35 & 0.06 & 0.099 \\
\hline Mo & 6.5 & 2.17 & 5.98 & 3.35 & 0.86 & 1.905 & 4.88 \\
\hline $\mathrm{Ni}$ & 31 & 19.1 & 41.8 & 23.1 & 18.4 & 4.05 & 29.74 \\
\hline $\mathrm{Cd}$ & 0.5 & 0.11 & 1.31 & 0.61 & 0.13 & 0.05 & 0.61 \\
\hline Co & 13.8 & 5.8 & 12.25 & 14.3 & 10.7 & 7.55 & 11.48 \\
\hline $\mathrm{Ti}$ & 2370 & 1570 & 1940 & 3860 & 3502 & 3650 & 2250 \\
\hline
\end{tabular}

Wulonggou Au district and wall-rock data are from [46]. The whole ore body data are the averages of the data from the four elevations.

The concentration center method is an empirical method that uses the zoning index method and employs the basic program of its calculation method for reference to calculate the concentration center of each element. The zoning sequence is $\mathrm{Mo}-\mathrm{Au}-\mathrm{Sb}-\mathrm{Ni}-\mathrm{Ag}-\mathrm{As}-$ $\mathrm{W}-\mathrm{Hg}$ (from high to low elevations) relative to the wall-rock, and $\mathrm{Au}-\mathrm{Mo}-\mathrm{Sb}-\mathrm{Ag}-\mathrm{Ni}-\mathrm{As}-$ $\mathrm{Hg}-\mathrm{W}$ relative to the Wulonggou Au district. 


\subsection{Pyrite Thermoelectric Properties}

The test results of in-situ pyrite thermoelectric property are shown in Supplementary Table S1 and Figure 9. Ore deposit models have been widely developed from pyrite thermoelectric data analysis $[39,47-49]$, and such data have been improved by the development of the in situ method [39].

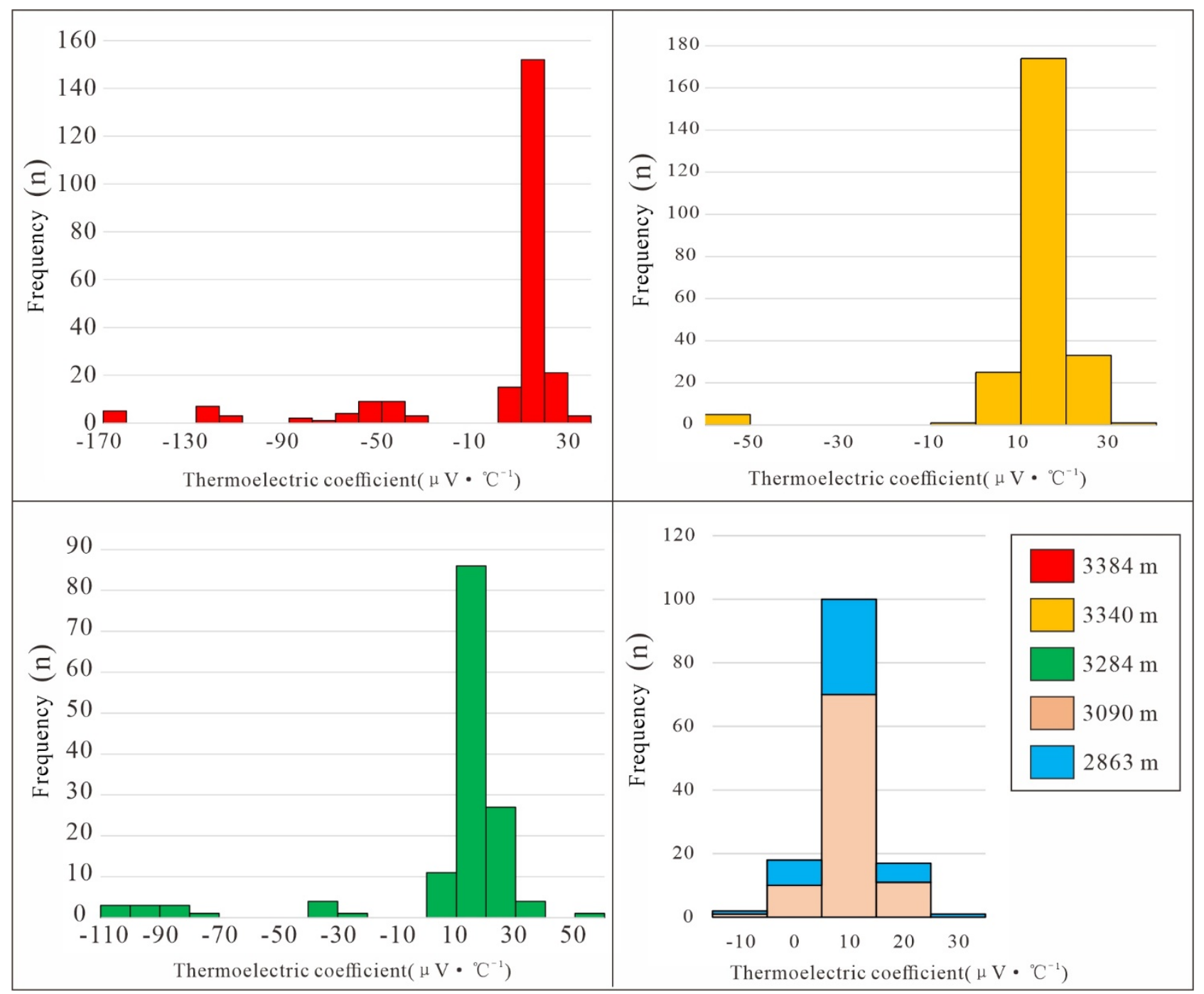

Figure 9. The histogram of thermoelectricity of pyrite.

The thermoelectric properties of pyrite at various elevations in the Yanjingou $\mathrm{Au}$ deposit are as follows (Figure 9): -165.71 to $30.9 \mu \mathrm{V} /{ }^{\circ} \mathrm{C}$ at $3384 \mathrm{~m}$, with a P-type ratio of $81.6 \% ; 34.16$ to $58.59 \mu \mathrm{V} /{ }^{\circ} \mathrm{C}$ at $3340 \mathrm{~m}$, with a P-type ratio of $97.5 \% ; 50.68$ to $106.19 \mu \mathrm{V} /{ }^{\circ} \mathrm{C}$ at $3284 \mathrm{~m}$, with a P-type ratio of $89.6 \% ; 9.18$ to $27.28 \mu \mathrm{V} /{ }^{\circ} \mathrm{C}$ at $3090 \mathrm{~m}$, with a P-type ratio of $98.9 \%$; 8.52 to $32.68 \mu \mathrm{V} /{ }^{\circ} \mathrm{C}$ at $2863 \mathrm{~m}$, with a P-type ratio of $97.8 \%$. The P-type ratio of the Yanjingou Au deposit is high $(>80 \%)$. The thermoelectric parameter calculated according to the above formula is $\mathrm{X}_{\mathrm{NP}}=-0.08742$, and the calculated denudation rate is $\gamma=50.02 \%$.

\section{Discussion}

\subsection{Implications for Prospecting from Primary Halo Geochemistry}

6.1.1. Calculation and Analysis of Primary Halo Geochemistry

Element concentrations with a high correlation with $\mathrm{Au}$ are $\mathrm{As}>\mathrm{Cu}>\mathrm{Co}>\mathrm{Ti}>\mathrm{Cd}$ $>\mathrm{Zn}>\mathrm{Ag}>\mathrm{Ba}>\mathrm{Hg}>\mathrm{Ni}>\mathrm{Sb}>\mathrm{Mo}>\mathrm{Bi}>\mathrm{W}>\mathrm{Pb}$, and cluster analysis showed that 
$\mathrm{Au}$ and As were the most evident elemental anomalies. In the analysis of mineralogy, we found that pyrite and arsenopyrite are most closely related, and polybasite or tetrahedrite often appear around it, which corresponds to the result that $\mathrm{Au}$ has a good correlation with As and $\mathrm{Cu}$. Two methods were used to determine the zoning sequence of some elements that are closely related to $\mathrm{Au}$ and yielded similar results. Arsenic and $\mathrm{Hg}$ are relatively constant, with little change from 3384 to $3090 \mathrm{~m}$ elevation and slightly lower enrichment, while $\mathrm{W}$ element tends to exhibit lower enrichment. Antimony and Ag are enriched in the middle and lower part, while Au exhibits little overall change, showing a slight upward enrichment. The supra-ore halo element As, which has the highest correlation with $\mathrm{Au}$, is relatively lower, which shows that the $3384-3090 \mathrm{~m}$ part of the ore body is shallow to moderate depth superimposed multiple ore bodies. The Au grade in the whole deposit may decrease gradually downward (i.e., $30 \%-50 \%$ of the ore is located at depth).

\subsubsection{Characteristic of Element Variation}

Previous studies of primary halo zoning [50-52] of Au deposits in China have revealed clear and similar axial zoning. In this study, we examined the primary halo ore zoning of the analyzed elements. The outer and upper parts of the ore body are generally rich in $\mathrm{B}-\mathrm{As}-\mathrm{Hg}-\mathrm{F}-\mathrm{Sb}-\mathrm{Ba}$, the central part of the ore body is generally rich in $\mathrm{Pb}-\mathrm{Ag}-\mathrm{Au}-\mathrm{Zn}-\mathrm{Cu}$, and the lower part of the ore body and sub-ore halo are generally rich in $\mathrm{W}-\mathrm{Bi}-\mathrm{Mo}-\mathrm{Mn}-$ $\mathrm{Ni}-\mathrm{Cd}-\mathrm{Co}-\mathrm{Ti}[33,34,44,49-51]$. Elements deposited during the medium-low-temperature stage $\left(50-200{ }^{\circ} \mathrm{C}\right)$ generally include $\mathrm{Ba}, \mathrm{Sr}, \mathrm{Hg}, \mathrm{Sb}, \mathrm{As}$, and $\mathrm{Au}$, and elements deposited during the high-medium-temperature stage $\left(200-350^{\circ} \mathrm{C}\right)$ generally include $\mathrm{Pb}, \mathrm{W}, \mathrm{Ag}$, $\mathrm{Cd}, \mathrm{Zn}$, and $\mathrm{Cu}$. The elements deposited during the vapor-rich high-temperature stage (500-350 ${ }^{\circ} \mathrm{C}$ ) generally include $\mathrm{Au}, \mathrm{As}, \mathrm{Bi}, \mathrm{Co}, \mathrm{Re}, \mathrm{Mo}, \mathrm{In}, \mathrm{Ca}, \mathrm{Zn}, \mathrm{W}, \mathrm{Fe}$, and $\mathrm{Sn}$ [50-52].

The elemental contents of the ore body at elevations of 3384 to $3090 \mathrm{~m}$ vary vertically (Figure 10; Tables 3 and 4). The contents of low-temperature elements that exhibit a high degree of correlation with Au do not significantly change with depth but exhibit a slight increase. The Au content decreases from 3384 to $3284 \mathrm{~m}$ and thereafter increases to $3090 \mathrm{~m}$. The As content decreases from 3384 to $3340 \mathrm{~m}$ and thereafter increases to $3090 \mathrm{~m}$. The $\mathrm{Hg}$ contents follows that of As, while the $\mathrm{Sb}$ content first decreases, then increases, and then decreases with increasing depth.

Table 4. Element anomaly for the four elevations in the Yanjingou Au deposit.

\begin{tabular}{|c|c|c|c|c|c|c|c|c|c|c|}
\hline & \multicolumn{5}{|c|}{ Relative to Wall-Rock } & \multicolumn{5}{|c|}{ Relative to the Wulonggou Au District } \\
\hline & $3384 \mathrm{~m}$ & $3340 \mathrm{~m}$ & $3284 \mathrm{~m}$ & $3090 \mathrm{~m}$ & Whole Ore Body & $3384 \mathrm{~m}$ & $3340 \mathrm{~m}$ & $3284 \mathrm{~m}$ & $3090 \mathrm{~m}$ & Whole Ore Body \\
\hline As & 162.96 & 77.47 & 185.86 & 202.02 & 152.20 & 438.41 & 208.42 & 500.00 & 543.48 & 409.44 \\
\hline $\mathrm{Hg}$ & 2.30 & 1.00 & 2.50 & 3.00 & 2.10 & 3.13 & 1.36 & 3.40 & 4.08 & 2.85 \\
\hline $\mathrm{Sb}$ & 2.73 & 1.31 & 5.78 & 1.07 & 2.93 & 150.79 & 72.25 & 319.66 & 59.21 & 161.91 \\
\hline $\mathrm{Ba}$ & 0.28 & 0.25 & 0.29 & 0.25 & 0.27 & 0.49 & 0.43 & 0.51 & 0.43 & 0.47 \\
\hline $\mathrm{Pb}$ & 0.37 & 0.36 & 20.27 & 0.54 & 5.36 & 0.20 & 0.19 & 10.93 & 0.29 & 2.89 \\
\hline $\mathrm{Ag}$ & 55.00 & 21.50 & 145.50 & 29.00 & 66.25 & 30.99 & 12.11 & 81.97 & 16.34 & 37.32 \\
\hline $\mathrm{Au}$ & 1112.50 & 542.50 & 252.50 & 671.88 & 700.63 & 4564.10 & 2225.64 & 1035.90 & 2756.41 & 2874.36 \\
\hline $\mathrm{Zn}$ & 2.41 & 0.54 & 3.30 & 2.11 & 2.13 & 2.23 & 0.50 & 3.04 & 1.95 & 1.96 \\
\hline $\mathrm{Cu}$ & 2.76 & 0.80 & 3.23 & 0.91 & 2.16 & 0.71 & 0.21 & 0.83 & 0.23 & 0.55 \\
\hline $\mathrm{W}$ & 7.11 & 8.22 & 7.67 & 17.56 & 8.84 & 1.65 & 1.91 & 1.78 & 4.07 & 2.05 \\
\hline $\mathrm{Bi}$ & 0.88 & 0.50 & 3.50 & 2.50 & 1.65 & 0.15 & 0.09 & 0.60 & 0.43 & 0.28 \\
\hline Mo & 3.41 & 1.14 & 3.14 & 1.76 & 2.56 & 7.56 & 2.52 & 6.95 & 3.90 & 5.67 \\
\hline $\mathrm{Ni}$ & 7.65 & 4.72 & 10.32 & 5.70 & 7.34 & 1.68 & 1.04 & 2.27 & 1.26 & 1.62 \\
\hline $\mathrm{Cd}$ & 10.00 & 2.20 & 26.20 & 12.20 & 12.20 & 3.85 & 0.85 & 10.08 & 4.69 & 4.69 \\
\hline Co & 1.83 & 0.77 & 1.62 & 1.89 & 1.52 & 1.29 & 0.54 & 1.14 & 1.34 & 1.07 \\
\hline $\mathrm{Ti}$ & 0.65 & 0.43 & 0.53 & 1.06 & 0.62 & 0.68 & 0.45 & 0.55 & 1.10 & 0.64 \\
\hline
\end{tabular}

The Abnormal degree are the elemental concentration of a section of the ore body divided by the wall-rock or Wulonggou Au district concentrations. 


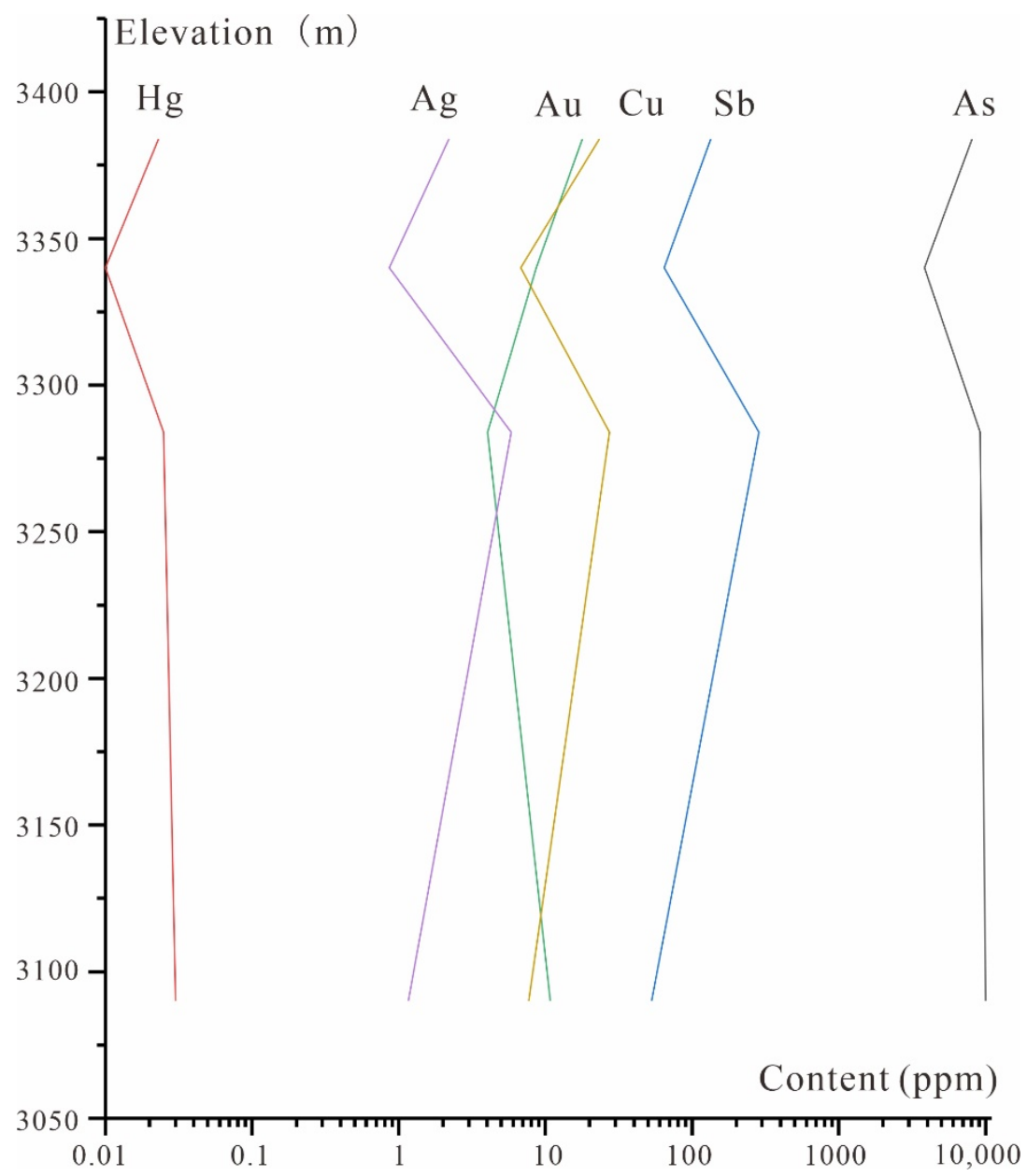

Figure 10. Changes in elemental concentrations in the supra-ore halo with height.

Differences in the contents of supra-ore halo elements ( $\mathrm{As}, \mathrm{Hg}$, $\mathrm{Sb}$, and $\mathrm{Ba}$ ), near-ore halo elements $(\mathrm{Pb}, \mathrm{Ag}, \mathrm{Au}, \mathrm{Zn}$, and $\mathrm{Cu}$ ), and sub-ore halo elements (W, Bi, Mo, Ni, Cd, Co, and $\mathrm{Ti}$ ) were examined by comparison with the wall-rocks of the Yanjingou Au deposit and average for the Wulonggou Au district (Table 4). This analysis showed high contents of $\mathrm{As}, \mathrm{Hg}$, and other elements in the supra-ore halo; $\mathrm{Ag}, \mathrm{Au}$, and other elements in the near-ore halo are high; and W, Mo, and other elements in the sub-ore halo.

The enrichments of elements in the supra-ore, near-ore, and sub-ore haloes are plotted with respect to elevation, and exhibit similar trends relative to the wall-rocks (Figure 11a,c,e) and the Wulonggou Au district (Figure 11b,d,e). Based on the observation of each elevation, the element contents are low at $3340 \mathrm{~m}$, while all the halo elements show anomalously high contents at $3284 \mathrm{~m}$. The Au grade in the near-ore halo gradually decreases from 3384 to $3284 \mathrm{~m}$, and then an increase to $3090 \mathrm{~m}$. This reflects the dilution and enrichment of elements caused by the superposition of other ore bodies on the primary halo. Therefore, we conclude that $3284 \mathrm{~m}$ is a location where small ore bodies are superimposed (Figure 12).

For the studied part of the ore body (elevations of 3384-3090 m), we assessed which elements are most enriched. If the ore body were to be enriched in supra-ore halo elements, this means that the ore body is shallow at present. If the ore body is enriched in sub-ore halo elements, this means that the ore body is the deep tail of the deposit, and most of the ore bodies may have been eroded and there is no deep ore potential. Figure 13a,b study on element enrichment intensity relative to wall-rock and the Wulonggou gold district, respectively, founding that supra-ore to near-ore element enrichment intensity is relatively high, indicating the overall 3384-3090 m section of ore body is shallow to central orebodies, relatively complete gold ore deposit is at least one third to half in the deeper parts, so the Yanjingou gold deposit has great ore-forming potential. 

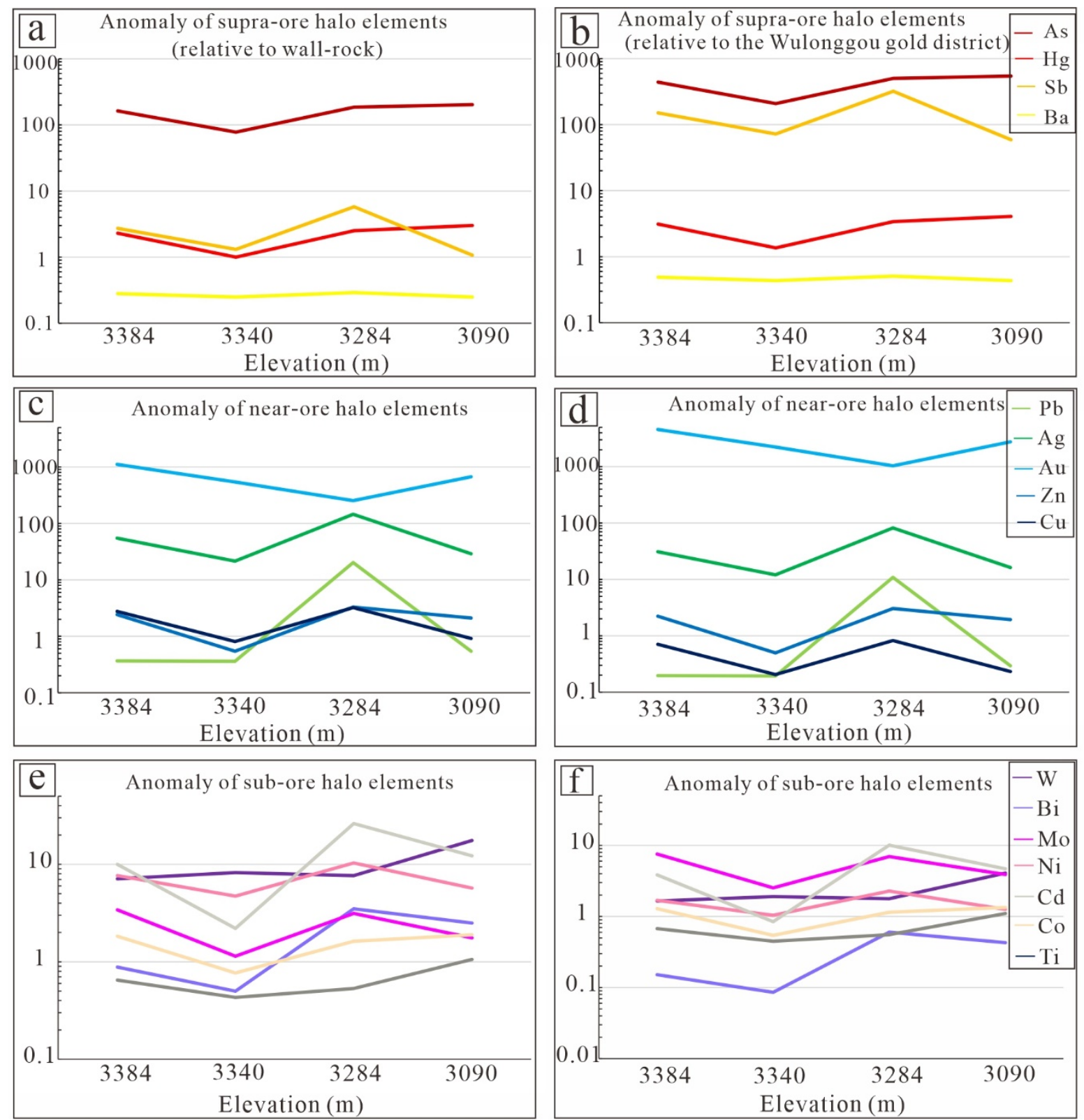

Figure 11. Variation characteristics and trends with different elevation of supra-, near-, and sub-ore halo elements. (a,c,e) are relative to wall-rock. (b,d,f) are relative to the Wulonggou gold district. 


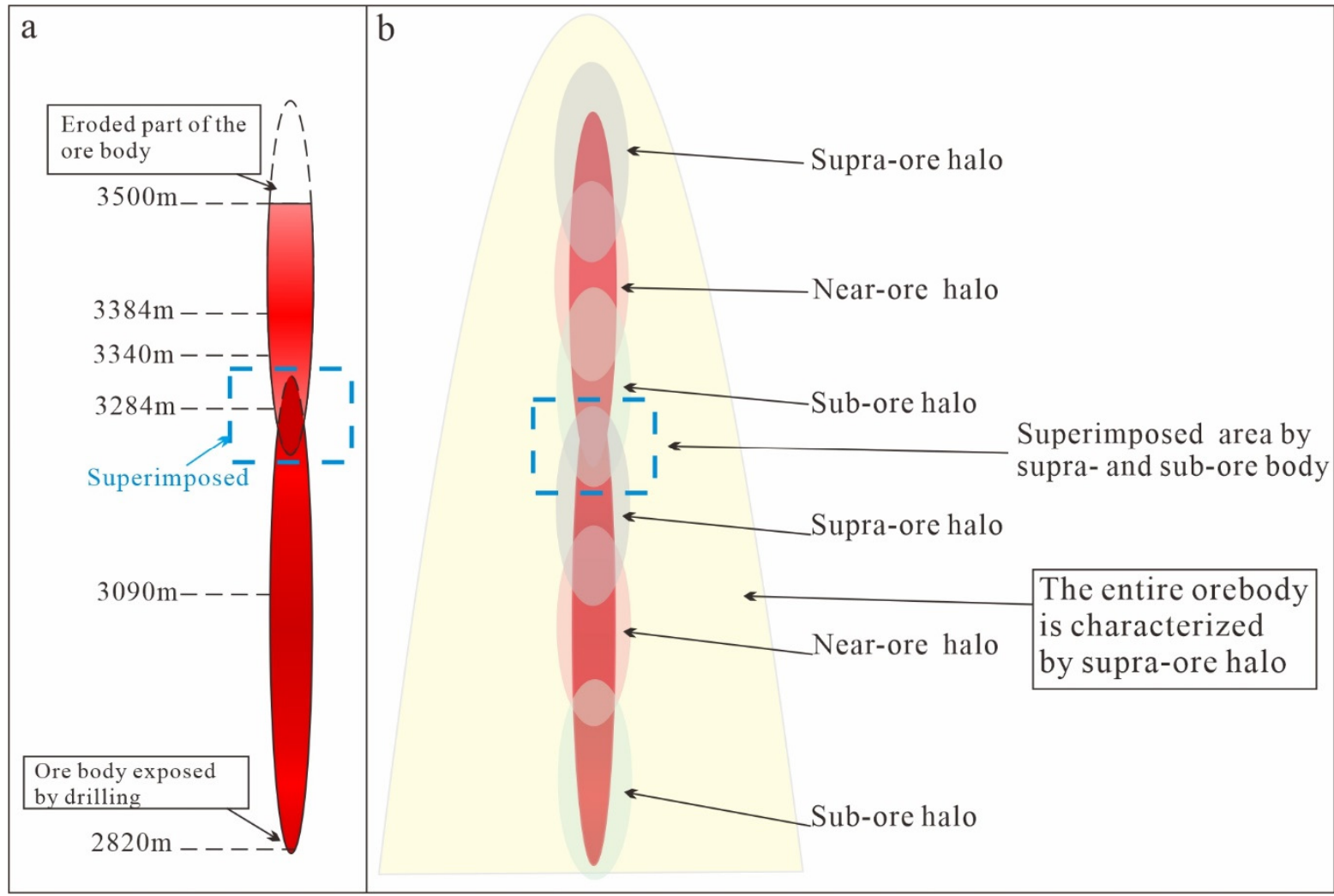

Figure 12. Schematic vertical section of the Yanjingou gold deposit. (a) The ore body were studied vertically from top to bottom and were divided into two small ore bodies; (b) Each independent small orebody conforms to the zoning criterion of primary halo, and for the whole orebody, it shows the characteristics of supra-ore hale.

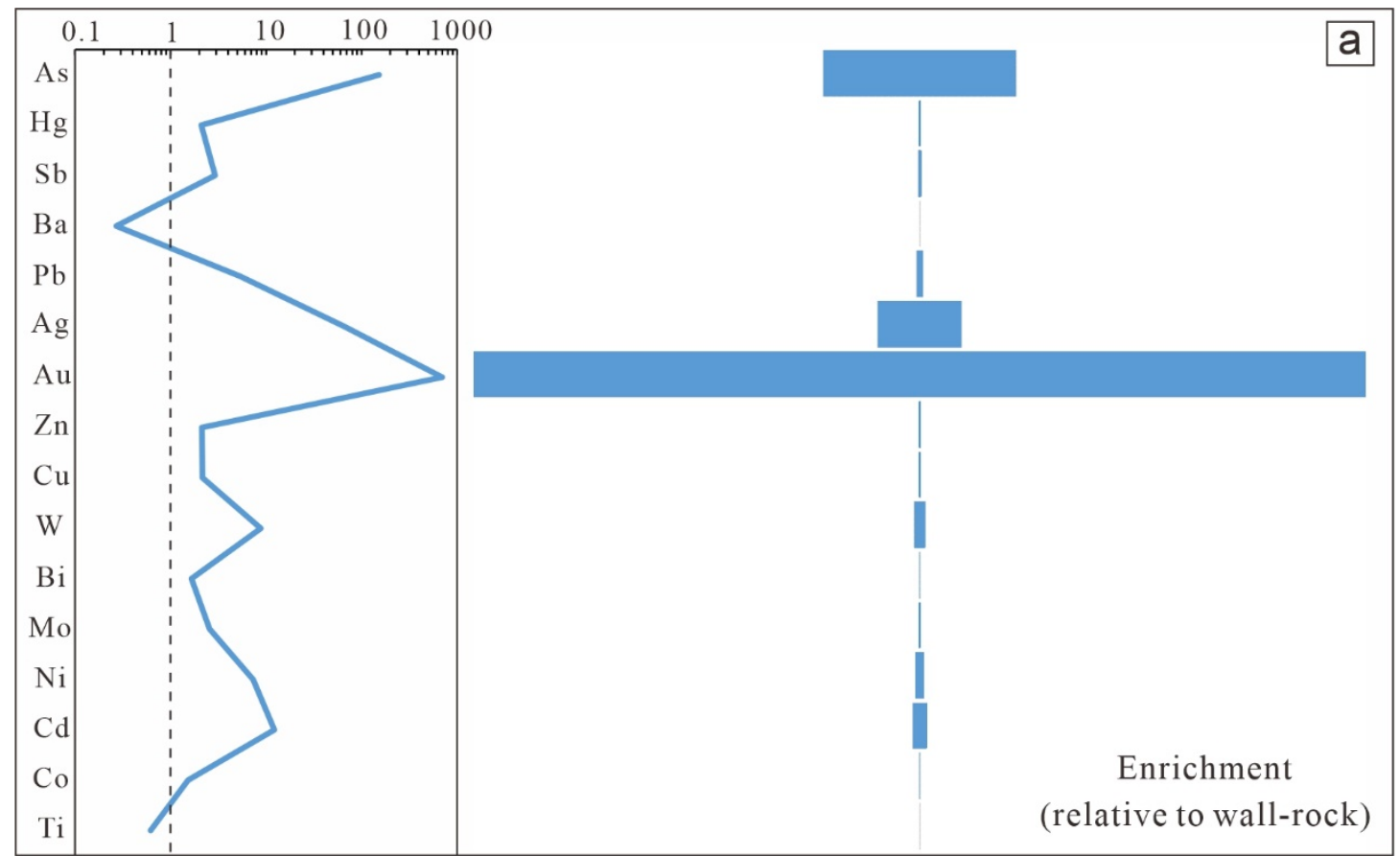

Figure 13. Cont. 


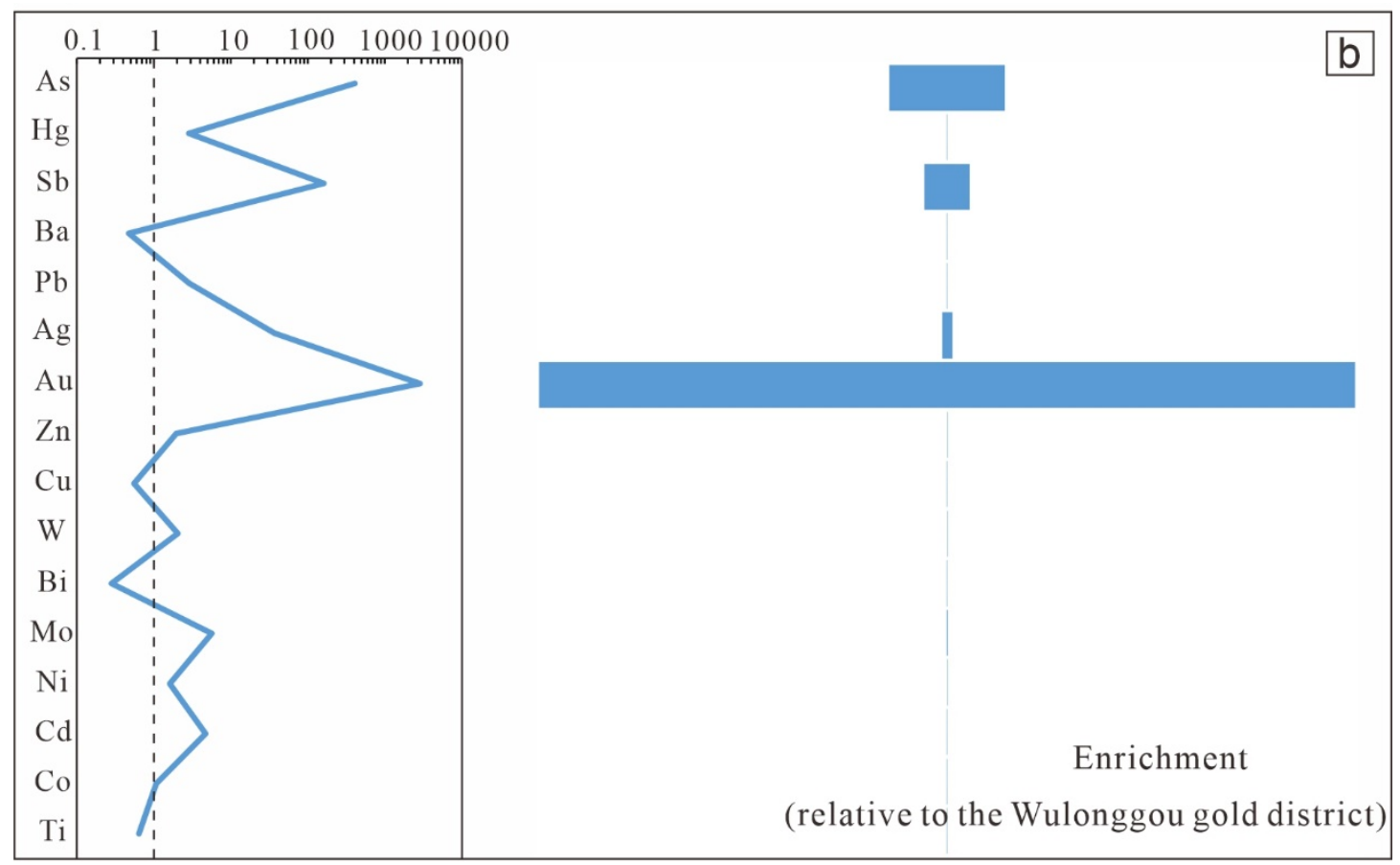

Figure 13. Elemental enrichment in the Yanjingou ore body relative to the wall-rocks and Wulonggou Au district. (a): elemental enrichment relative to the wall-rocks; (b): elemental enrichment relative to the Wulonggou Au district.

\subsection{Implications for Prospecting from In Situ Pyrite Thermoelectricity}

Pyrite is a semiconductor mineral with a band gap of $0.95 \mathrm{eV}$, which usually has two semiconductor properties: P-type (hole conduction) and N-type (electron conduction) $[40,53]$. The thermoelectric coefficient $\alpha$ value and conduction type of pyrite are affected by homogeneously distributed impurities in the pyrite, defects in the crystal structure, density, and external excitation conditions (i.e., temperature and pressure gradients). Since these factors are affected by mineralization depth, the thermoelectric properties of pyrite can be used as an indicator of depth $[40,41,48,54]$. Pridmore and Shuey (1976) showed that the lattice of As-containing pyrite is larger than that of free pyrite, and that P-type conductive pyrite can more readily adsorb $\mathrm{Au}$ [38]. The presence of As and $\mathrm{Sb}$ can lead to the formation of P-type pyrite. The lattice distortion of P-type pyrite reduces the $\mathrm{Au}^{+}$content of the pyrite, leading to the precipitation of $\mathrm{Au}[55,56]$. The sample of the Yanjingou gold deposits in the different level from high to low shows certain similarity and the law of carrier contains additional electronic N-pyrite and lose the outermost electron P-type of pyrite in the process of Au deposits have different meaning, pyrite P-type rate to different depth of orebody location for instructions. In simple terms, P-type multiple ore bodies are shallow (top) and N-type multiple ore bodies are deep (bottom).

The high ratio of P-type pyrite in the Yanjingou Au deposit performance indicates the studied ore bodies are shallow and from near the top of the deposit (Figure 14). An increasing proportion of $\mathrm{N}$-type pyrite can reflect ore body location down, and we study the elevation of pyrite P-type rate assumes the wave of change, suggests that the mineralization is superposed, because P-type pyrite should be reduced from top to bottom, and N-type pyrite should be increased in general. From the denudation rate $(\gamma=50.02 \%)$, it also can be roughly inferred that the observed orebody is located in more than half of the ore body, and half of the deep orebody has not been found. The in situ thermoelectric properties of pyrite are basically the same as those of primary halo geochemistry, which all reflect that the exposed ore body is in a shallow state and there is still a good prospecting potential in the deep. 


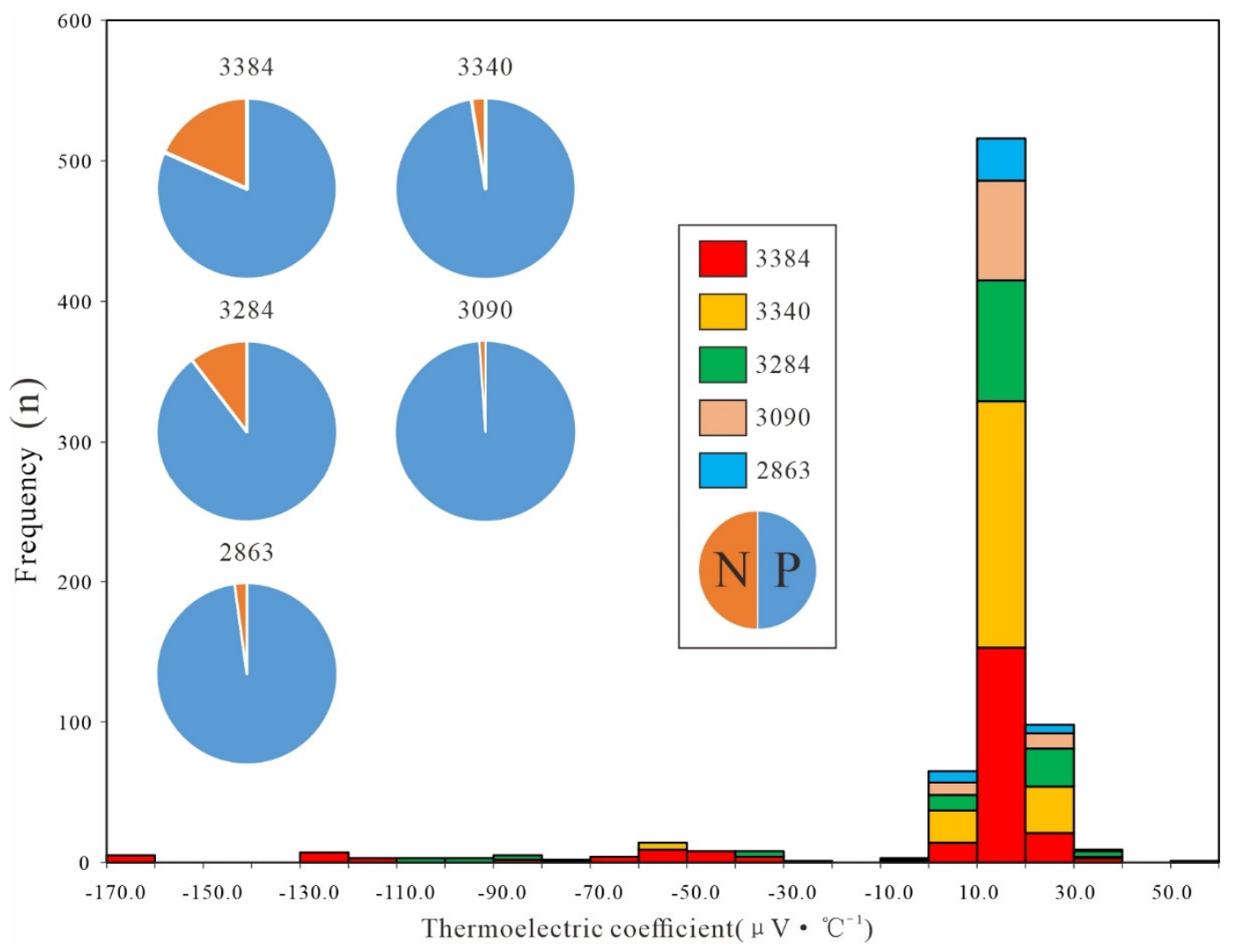

Figure 14. Thermoelectric characteristics of pyrite.

\subsection{Mineralization Prediction Model and Prospecting Potential}

The use of primary halo geochemical methods to predict blind ore is mainly achieved through the commonality of the best indicator element combination, the zoning sequence, and the coexistence criterion of superimposed halo [33,34,44,51,57-59]. Gold is the most important indicator element, and Ag is one of the important associated elements. In case of an $\mathrm{Au}$ anomaly, a large $\mathrm{As}, \mathrm{Hg}$, and $\mathrm{Sb}$ anomaly indicates the presence of a deep-level concealed ore body. In addition, a large $\mathrm{Cu}, \mathrm{Pb}$, and $\mathrm{Zn}$ anomaly may indicate the presence of a relatively rich ore body. Sub-ore halo indicator elements, such as Bi and Mo, usually mark the tail of an ore body. If supra-ore halo elements, such as $\mathrm{As}, \mathrm{Hg}$, and $\mathrm{Sb}$, have large anomalies along with sub-ore halo indicator elements, such as Bi and Mo, a concealed or large extension ore body can be inferred. These geochemical constraints and pyrite thermoelectric properties of the primary halo can be used to construct an ore deposit model.

We established a mineralization prediction model for the Yanjingou Au deposit (Figure 15). In fact, each ore deposit consists of many ore bodies. During mineralization, hydrothermal fluids migrated along cracks and other channels (i.e., ore guiding structures), and the ores formed under suitable physical and chemical conditions. In the case of a large deposit, the area of hydrothermal alteration is extensive. Overall, it is satisfactory that the primary halos metallogenic theory can show the supra-ore halo, near-ore halo, and sub-ore halo enrichment characteristics for each element. From the point of view of each small ore body, it also has this characteristic. There are obvious indicator elements in the head and tail of each small ore body, thus our model is established. Large enrichments in $\mathrm{As}, \mathrm{Hg}, \mathrm{Sb}$, and $\mathrm{Ba}$ are typical feature of the Yanjingou Au deposit at elevations of 3384-3090 m. The elemental features at the surface $(3500 \mathrm{~m})$ indicate that a small amount of the ore body has been eroded. The borehole data at $2820 \mathrm{~m}$ indicates that there is a deep ore deposit, which further confirms our speculation. The high ratio of P-type can also reflect our study belongs to shallow ore body, namely partial deposit at the top of the position. At the same time, calculated denudation rate was about $50 \%$ and can also be used to speculate that at least 
half of concealed for the exploration of ore body deep still exist, in general, the Yanjingou Au deposit ore-forming prospect is very good. The study has important scientific guiding significance for the breakthrough of prospecting and exploration.

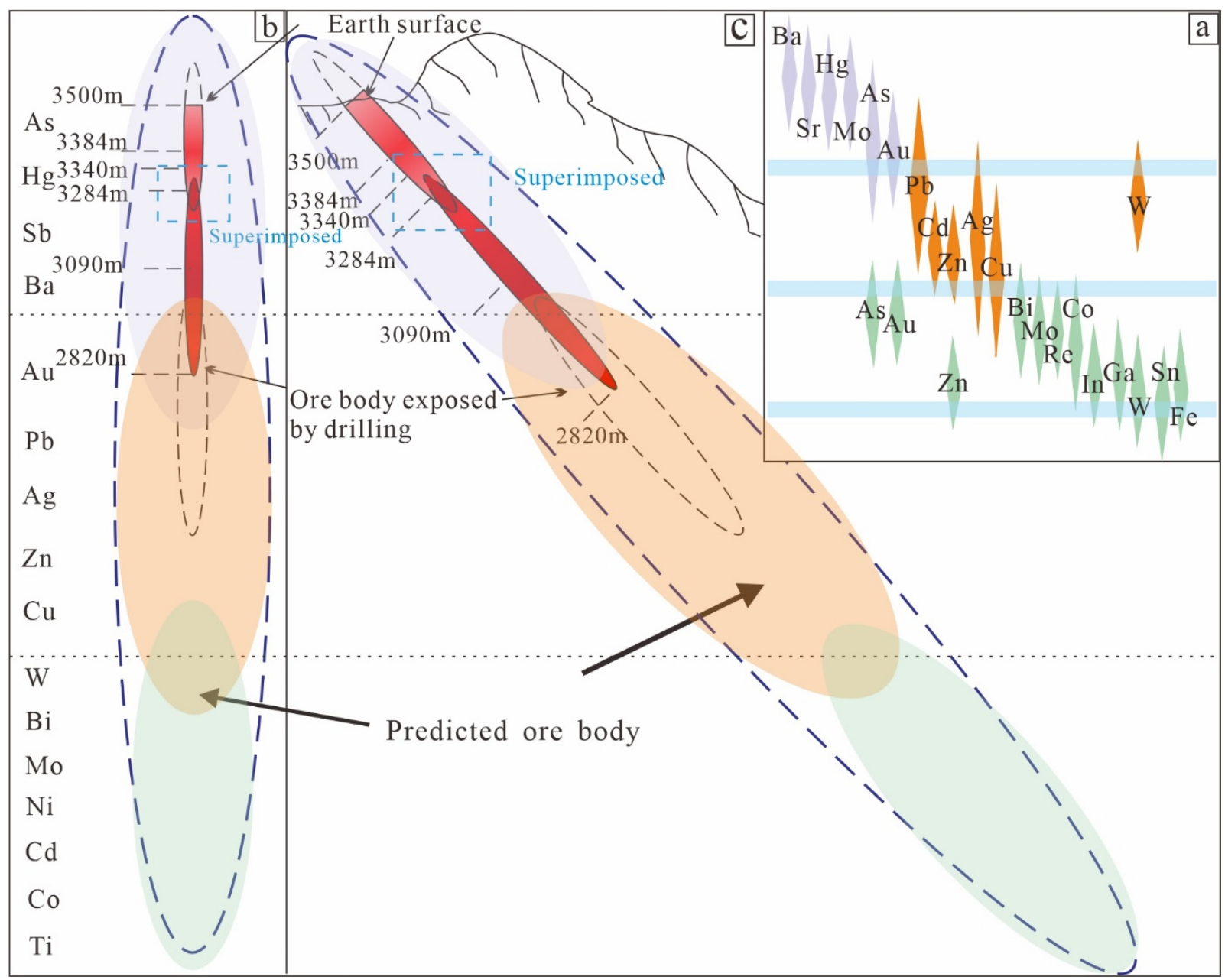

Figure 15. Mineralization prediction model for the Yanjingou ore body. (a): high to low temperature elemental zoning, (b): vertical diagram, and (c) metallogenic prediction profile.

\section{Conclusions}

1. The Yanjingou Au deposit is a fractured- and altered-type Au deposit that is rich in arsenopyrite.

2. Element concentrations with a high correlation with $\mathrm{Au}$ are $\mathrm{As}>\mathrm{Cu}>\mathrm{Co}>\mathrm{Ti}>\mathrm{Cd}>$ $\mathrm{Zn}>\mathrm{Ag}>\mathrm{Ba}>\mathrm{Hg}>\mathrm{Ni}>\mathrm{Sb}>\mathrm{Mo}>\mathrm{Bi}>\mathrm{W}>\mathrm{Pb}$. Cluster analysis showed that $\mathrm{Au}$ and As were the most evident elemental anomalies.

3. Axial element zoning determined with the concentration center and zoning index methods is consistent, and $\mathrm{As}, \mathrm{Hg}, \mathrm{Ag}$, and $\mathrm{Sb}$ contents tend to cluster downward, suggesting good prospects for further deep mineralization.

4. Primary halo geochemistry showed the characteristics of supra-ore halo elements (As, $\mathrm{Hg}, \mathrm{Sb}, \mathrm{Ag}$ and $\mathrm{Au}$ ), which indicate that the studied ore body is a supra-ore halo and represents the shallow part of the overall deposit.

5. In situ pyrite thermoelectric analysis showed that the observed ore body are dominated by P-type pyrite $(>80 \%)$, and the amount of denudation is $50 \%$, which again indicates that the ore body presents the shallow part of the deposit.

6. A mineralization prediction model shows that the Yanjingou Au deposit has good mineralization and a high prospecting potential. 
Supplementary Materials: The following are available online at https:/ / www.mdpi.com/article/10 $.3390 / \min 11101117 / \mathrm{s} 1$.

Author Contributions: Conceptualization, J.W. and Q.Z.; formal analysis, Z.Z.; investigation, X.L., F.X., G.L. and Z.W.; resources, Q.Z. and J.W.; writing-original draft preparation, J.W.; writingreview and editing, Q.Z. and Z.Z.; visualization, K.Y.; supervision, Q.Z.; funding acquisition, H.F. All authors have read and agreed to the published version of the manuscript.

Funding: This research was supported by the Second Tibetan Plateau Scientific Expedition and Research Program (STEP) (Grant 2019QZKK08023) and National Natural Science Foundation of China (Grant 42002078).

Data Availability Statement: The data presented in this study are openly available.

Acknowledgments: We thank our team members who contributed to this study, including Bing Yu, Ruiliang Wang, and Wei Xie. We also thank the staff of the mining and exploration companies who assisted us with the fieldwork.

Conflicts of Interest: The authors declare no conflict of interest.

\section{References}

1. Groves, D.I.; Santosh, M. Craton and thick lithosphere margins: The sites of giant mineral deposits and mineral provinces. Gondwana Res. 2020. [CrossRef]

2. Goldfarb, R.J.; Groves, D.I. Orogenic gold: Common or evolving fluid and metal sources through time. Lithos 2015, 233, 2-26. [CrossRef]

3. Goldfarb, R.J.; Groves, D.I.; Gardoll, S. Orogenic gold and geologic time: A global synthesis. Ore Geol. Rev. 2001, 18, 1-75. [CrossRef]

4. Groves, D.I.; Santosh, M.; Deng, J.; Wang, Q.; Yang, L.; Zhang, L. A holistic model for the origin of orogenic gold deposits and its implications for exploration. Miner. Depos. 2020, 55, 275-292. [CrossRef]

5. Patten, C.G.C.; Pitcairn, I.K.; Molnár, F.; Kolb, J.; Beaudoin, G.; Guilmette, C.; Peillod, A. Gold mobilization during metamorphic devolatilization of Archean and Paleoproterozoic metavolcanic rocks. Geology 2020, 48, 1110-1114. [CrossRef]

6. Chen, J.; Fu, L.; Selby, D.; Wei, J.; Zhao, X.; Zhou, H. Multiple episodes of gold mineralization in the East Kunlun Orogen, western Central Orogenic Belt, China: Constraints from Re-Os sulfide geochronology. Ore Geol. Rev. 2020, 123, 103587. [CrossRef]

7. Zhang, J.; Ma, C.; Li, J.; Pan, Y. A possible genetic relationship between orogenic gold mineralization and post-collisional magmatism in the eastern Kunlun Orogen, western China. Ore Geol. Rev. 2017, 81, 342-357. [CrossRef]

8. Groves, D.I.; Goldfarb, R.J.; Gebre-Mariam, M.; Hagemann, S.G.; Robert, F. Orogenic gold deposits: A proposed classification in the context of their crustal distribution and relationship to other gold deposit types. Ore Geol. Rev. 1998, 13, 7-27. [CrossRef]

9. Li, X.H.; Fan, H.R.; Liang, G.Z.; Zhu, R.X.; Yang, K.F.; Steele-MacInnis, M.; Hu, H.L. Texture, trace elements, sulfur and He-Ar isotopes in pyrite: Implication for ore-forming processes and fluid source of the Guoluolongwa gold deposit, East Kunlun metallogenic belt. Ore Geol. Rev. 2021, 136, 104260. [CrossRef]

10. Zhong, C.L.; Zhong, K.H.; Ran, F.Q. Geological Characters of Yanjingou Gold Mine in Qinghai Province Wulonggou Area. Sichuan Nonferrous Met. 2017, 1006-4079, 32-04. (In Chinese with English Abstract)

11. Yuan, W.; Mo, X.; Zhang, A.; Chen, X.; Duan, H.; Li, X.; Hao, N.; Wang, X. Fission track thermochronology evidence for multiple periods of mineralization in the Wulonggou Gold deposits, eastern Kunlun Mountains, Qinghai Province. J. Earth Sci. 2013, 24, 471-478. [CrossRef]

12. Chen, B.L.; Wang, Y.; Han, Y.; Chen, J.L. Metallogenic age of Yanjingou gold deposit in Wulonggou gold orefield, eastern Kunlun Mountains. Mineral. Depos. 2019, 38, 541-556. (In Chinese with English Abstract)

13. Zhang, M. Characteristics of $\mathrm{Cu}-\mathrm{Pb}$-Zn in Ore-Bearing Structure of Yanjingou Gold Deposit in Dulan, Qinghai Province; Chengdu University of Technology: Chengdu, China, 2016. (In Chinese with English Abstract)

14. Dong, Y. Study on Petrographic Characteristics of the Yanjingou Gold Deposit in Dulan County, Qinghai Province; Chengdu University of Technology: Chengdu, China, 2018; p. 71. (In Chinese with English Abstract)

15. Xia, R.; Wang, C.; Qing, M.; Li, W.; Carranza, E.J.M.; Guo, X.; Ge, L.; Zeng, G. Zircon U-Pb dating, geochemistry and Sr-Nd-Pb$\mathrm{Hf}-\mathrm{O}$ isotopes for the Nan'getan granodiorites and mafic microgranular enclaves in the East Kunlun Orogen: Record of closure of the Paleo-Tethys. Lithos 2015, 234-235, 47-60. [CrossRef]

16. Dong, Y.; He, D.; Sun, S.; Liu, X.; Zhou, X.; Zhang, F.; Yang, Z.; Cheng, B.; Zhao, G.; Li, J. Subduction and accretionary tectonics of the East Kunlun orogen, western segment of the Central China Orogenic System. Earth Sci. Rev. 2018, 186, 231-261. [CrossRef]

17. Yu, M.; Dick, J.M.; Feng, C.; Li, B.; Wang, H. The tectonic evolution of the East Kunlun Orogen, northern Tibetan Plateau: A critical review with an integrated geodynamic model. J. Asian Earth Sci. 2020, 191, 104168. [CrossRef]

18. Chen, L.; Sun, Y.; Pei, X.-Z.; Gao, M.; Feng, T. Northernmost paleo-tethyan oceanic basin in Tibet: Geochronological evidence from 40Ar/39Arage dating of Dur'ngoi ophiolite. Chin. Sci. Bull. 2001, 46, 1203-1205. [CrossRef] 
19. Chen, Y.X.; Pei, X.Z.; Li, R.B.; Li, Z.C.; Pei, L.; Chen, G.C.; Liu, C.J.; Li, X.B.; Yang, J. Zircon U-Pb age, geochemical and tectonic significance of metavolcanic rocks from Naij Tal Group, east section of east Kunlun. Earth Sci. Front. 2013, 20, 240-254. (in Chinese with English Abstract)

20. Huang, H.; Niu, Y.; Nowell, G.; Zhao, Z.; Yu, X.; Zhu, D.-C.; Mo, X.; Ding, S. Geochemical constraints on the petrogenesis of granitoids in the East Kunlun Orogenic belt, northern Tibetan Plateau: Implications for continental crust growth through syn-collisional felsic magmatism. Chem. Geol. 2014, 370, 1-18. [CrossRef]

21. Chen, N.; Sun, M.; Wang, Q.; Zhao, G.; Chen, Q.; Shu, G. EMP chemical ages of monazites from Central Zone of the eastern Kunlun Orogen: Records of multi-tectonometamorphic events. Chin. Sci. Bull. 2007, 52, 2252-2263. [CrossRef]

22. Shao, F.; Niu, Y.; Liu, Y.; Chen, S.; Kong, J.; Duan, M. Petrogenesis of Triassic granitoids in the East Kunlun Orogenic Belt, northern Tibetan Plateau and their tectonic implications. Lithos 2017, 282-283, 33-44. [CrossRef]

23. Ding, Q.-F.; Song, K.; Zhang, Q.; Yan, W.; Liu, F. Zircon U-Pb geochronology and Hf isotopic constraints on the petrogenesis of the Late Silurian Shidonggou granite from the Wulonggou area in the Eastern Kunlun Orogen, Northwest China. Int. Geol. Rev. 2018, 61, 1666-1689. [CrossRef]

24. Zhao, X.; Wei, J.; Fu, L.; Huizenga, J.M.; Santosh, M.; Chen, J.; Wang, D.; Li, A. Multi-stage crustal melting from Late Permian back-arc extension through Middle Triassic continental collision to Late Triassic post-collisional extension in the East Kunlun Orogen. Lithos 2020, 360-361, 105446. [CrossRef]

25. Chen, J.; Wei, J.; Fu, L.; Li, H.; Zhou, H.; Zhao, X.; Zhan, X.; Tan, J. Multiple sources of the Early Mesozoic Gouli batholith, Eastern Kunlun Orogenic Belt, northern Tibetan Plateau: Linking continental crustal growth with oceanic subduction. Lithos 2017, 29-293, 161-178. [CrossRef]

26. Chen, J.; Fu, L.; Wei, J.; Selby, D.; Zhang, D.; Zhou, H.; Zhao, X.; Liu, Y. Proto-Tethys magmatic evolution along northern Gondwana: Insights from Late Silurian-Middle Devonian A-type magmatism, East Kunlun Orogen, Northern Tibetan Plateau, China. Lithos 2020, 356-357, 105304. [CrossRef]

27. Bian, Q.-T.; Li, D.-H.; Pospelov, I.; Yin, L.-M.; Li, H.-S.; Zhao, D.-S.; Chang, C.-F.; Luo, X.-Q.; Gao, S.-L.; Astrakhantsev, O.; et al. Age, geochemistry and tectonic setting of Buqingshan ophiolites, North Qinghai-Tibet Plateau, China. J. Asian Earth Sci. 2004, 23, 577-596. [CrossRef]

28. Liu, Z.Q.; Pei, X.Z.; Li, R.B.; Li, Z.C.; Chen, Y.X.; Gao, J.M.; Liu, C.J.; Wang, X.L.; Wei, F.G.; Zhang, G.; et al. Geological characteristics of the Buqingshan tectonic melange belt in the southern margin of East Kunlun and its tectonic implications. Geol. Bull. China 2011, 30, 1182-1195. (In Chinese with English Abstract)

29. Xin, W.; Sun, F.-Y.; Li, L.; Yan, J.-M.; Zhang, Y.-T.; Wang, Y.-C.; Shen, T.-S.; Yang, Y.-J. The Wulonggou metaluminous A2-type granites in the Eastern Kunlun Orogenic Belt, NW China: Rejuvenation of subduction-related felsic crust and implications for post-collision extension. Lithos 2018, 312-313, 108-127. [CrossRef]

30. Templ, M.; Filzmoser, P.; Reimann, C. Cluster analysis applied to regional geochemical data: Problems and possibilities. Appl. Geochem. 2008, 23, 2198-2213. [CrossRef]

31. Zuo, R.; Xia, Q.; Wang, H. Compositional data analysis in the study of integrated geochemical anomalies associated with mineralization. Appl. Geochem. 2013, 28, 202-211. [CrossRef]

32. Reimann, C.; Filzmoser, P.; Hron, K.; Kynclova, P.; Garrett, R.G. A new method for correlation analysis of compositional (environmental) data-A worked example. Sci. Total Environ. 2017, 607-608, 965-971. [CrossRef]

33. Li, Y.; Zhang, D.; Dai, L.; Wan, G.; Hou, B. Characteristics of structurally superimposed geochemical haloes at the polymetallic Xiasai silver-lead-zinc ore deposit in Sichuan Province, SW China. J. Geochem. Explor. 2016, 169, 100-122. [CrossRef]

34. Li, H.; Yu, B.; Wei, J. A new practical ideal model of structural superimposed halos for prediction of deep blind hydrothermal deposits and its significance. Geol. Explor. 2020, 56, 889-897. (In Chinese with English Abstract)

35. Beus, A.A.; Gregorian, S.V. Geochemical Exploration Methods for Mineral. Deposits; Applied Publishing: Wilmette, IL, USA, 1977; p. 287.

36. Harraz, H.Z.; Hamdy, M.M. Zonation of primary haloes of Atud auriferous quartz vein deposit, Central Eastern Desert of Egypt: A potential exploration model targeting for hidden mesothermal gold deposits. J. African Earth Sci. 2015, 101, 1-18. [CrossRef]

37. Wu, J.C.; Shen, J.F.; Li, G.W.; Li, S.R.; Qiu, H.C.; He, Z.Y.; Li, J.P. The Improved Method for Measuring Thermoelectric Property of Pyrite and Its Implication for Exploring Gold Resources - A Case Study of the Wulong Gold Deposit in Liaoning Province. Bull. Mineral. Petrol. Geochem. 2020, 39, 284-292. (In Chinese with English Abstract)

38. Pridmore, D.F.; Shuey, R.T. The electrical resistivity of galena, pyrite, and chalcopyrite. Am. Mineral. 1976, 61, $248-259$.

39. Chen, G.; Shao, W.; Sun, D. Genetic Mineralogy of Gold Deposits in Jiaodong Region with Emphasis on Gold Prospecting; Chongqing Publishing House: Chongqing, China, 1989. (In Chinese)

40. Abraitis, P.K.; Pattrick, R.A.D.; Vaughan, D.J. Variations in the compositional, textural and electrical properties of natural pyrite: A review. Int. J. Mineral. Proces. 2004, 74, 41-59. [CrossRef]

41. Shen, J.F.; Li, S.R.; Ma, G.G.; Liu, Y.; Yu, H.J.; Liu, H.M. Tyoomorphic characteristics of pyrite from the Linglong gold deposit: Its vertical variation and prospecting significance. Earth Sci. Front. 2013, 20, 55-75. (In Chinese with English Abstract)

42. Xue, J.; Li, S.; Sun, W.; Zhang, Y.; Zhang, X. Characteristics of the genetic mineralogy of pyrite and its significance for prospecting in the Denggezhuang gold deposit, Jiaodong Peninsula, China. Sci. Chin. Earth Sci. 2014, 57, 644-661. [CrossRef]

43. Wang, G.; Feng, Y.; Carranza, E.J.M.; Li, R.; Li, Z.; Feng, Z.; Zhao, X.; Wang, D.; Kong, L.; Jia, W.; et al. Typomorphic characteristics of pyrite: Criteria for 3D exploration targeting in the xishan gold deposit, China. J. Geochem. Explor. 2016, 164, 136-163. [CrossRef] 
44. Li, H.; Yu, B.; Wei, H.; Sun, F.Z.; Li, Y.C.; Wang, J.; Wei, Z.X.; Li, S. New breakthrough in the prediction of deep blind ore in mining area: Structural superimposed halo for blind ore method. Mineral. Explor. 2019, 10, 3070-3073. (In Chinese with English Abstract)

45. Chen, Y.; Liu, H. Delineation of potential mineral resources region based on geo-anomaly unit. J. China Univ. Geosci. 2000, 11, 158-163. (In Chinese with English Abstract)

46. Zhu, G. Metallogenic Analysis and Prediction Application of Typical Gold Deposits in East Kunlun Based on Structural Superposition: Taking Wulonggou Gold Deposit as an Example; Qinghai University: Qinghai, China, 2016. (In Chinese with English Abstract)

47. Shen, J.F.; Li, S.R.; Du, B.S.; Wang, D.L.; Peng, Z.D.; Bo, H.J.; Li, K.; Liu, H.M.; Liu, S.Q. Minerals Alteration and Typomorph in Gold Deposit and Their Implications for Prospecting. Bull. Mineral. Petrol. Geochem. 2018, 37, 157-167. (In Chinese with English Abstract)

48. Alam, M.; Li, S.-R.; Santosh, M.; Shah, A.; Yuan, M.-W.; Khan, H.; Qureshi, J.A.; Zeng, Y.-J. Morphological, thermoelectrical, geochemical and isotopic anatomy of auriferous pyrite from the Bagrote valley placer deposits, North Pakistan: Implications for ore genesis and gold exploration. Ore Geol. Rev. 2019, 112, 103008. [CrossRef]

49. Li, C.-L.; Li, L.; Yuan, M.-W.; Alam, M.; Li, S.-R.; Santosh, M.; Deng, C.-Z.; Liu, H.; Xu, G.-Z. Study on pyrite thermoelectricity, ore-forming fluids and H-O-Rb-Sr isotopes of the Yongxin gold deposit, Central Asian Orogenic Belt: Implications for ore genesis and exploration. Ore Geol. Rev. 2020, 121, 103568. [CrossRef]

50. Li, H.; Zhang, W.H.; Liu, B.L.; Wang, J.C.; Guo, R.X. The study on axial zonality sequence of primary halo and some criteria for the application of this sequence for major types of gold deposits in China. Geol. Explor. 1999, 35, 32-35. (In Chinese with English Abstract)

51. Li, H.; Yu, B.; Li, D.L.; Zhang, G.Y. Prediction of blind ore bodies using structural superimposed halo and research methods. Geol. Explor. 2013, 49, 154-161. (In Chinese with English Abstract)

52. Shao, Y. Study on primary element zoning of ore deposits and its application in geochemical prospecting. Geol. Explor. 1984, 2, 47-55. (In Chinese with English Abstract)

53. Schieck, R.; Hartmann, A.; Fiechter, S.; Könenkamp, R.; Wetzel, H. Electrical properties of natural and synthetic pyrite (FeS2) crystals. J. Mater. Res. 2011, 5, 1567-1572. [CrossRef]

54. Liu, H.N.; Liu, J.J.; Li, X.W.; Liu, C.H.; Dai, H.Z.; Tao, Y.L.; Wang, J.F.; Du, Y.D.; Fan, Y.F. Thermoelectric characteristics of pyrite from the Xindigou gold deposit in Inner Mongolia and its significance on deep prospecting. Geol. China 2018, 45, 819-838. (In Chinese with English Abstract)

55. Morimoto, K. Relationship among the Trace Element Composition, Crystal Morphology and Physical Property of Natural Pyrite. Unpublished Ph.D. Thesis, Tohoku University, Sendai, Japan, 1992; p. 160.

56. Fuchs, S.; Williams-Jones, A.E.; Przybylowicz, W.J. The origin of the gold and uranium ores of the Black Reef Formation, Transvaal Supergroup, South Africa. Ore Geol. Rev. 2016, 72, 149-164. [CrossRef]

57. Fedikow, M.A.F.; Govett, G.J.S. Geochemical alteration haloes around the Mount Morgan gold-copper deposit, Queensland, Australia. J. Geochem. Explor. 1985, 24, 247-272. [CrossRef]

58. Eilu, P.; Groves, D.I. Primary alteration and geochemical dispersion haloes of Archaean orogenic gold deposits in the Yilgarn Craton: The pre-weathering scenario. Geochem. Explor. Environ. Anal. 2001, 1, 183-200. [CrossRef]

59. Goldberg, I.S.; Abramson, G.Y.; Los, V.L. Depletion and enrichment of primary haloes: Their importance in the genesis of and exploration for mineral deposits. Geochem. Explor. Environ. Anal. 2003, 3, 281-293. [CrossRef] 